\title{
Effect of pH on Zero Valent Iron Performance in Heterogeneous Fenton and Fenton-Like Processes: A Review
}

\author{
Fatemeh Rezaei $^{1}$ (D) and Davide Vione ${ }^{2, *(\mathbb{D})}$ \\ 1 Department of Environmental Sciences, Faculty of Natural Resources and Marine Sciences, \\ Tarbiat Modares University, Noor 46414356, Iran; fateme.rezaei@modares.ac.ir \\ 2 Department of Chemistry, University of Turin, Via Pietro Giuria 5, I-10125 Turin, Italy \\ * Correspondence: davide.vione@unito.it; Tel.: +39-011-670-5296
}

Received: 7 November 2018; Accepted: 27 November 2018; Published: 29 November 2018

\begin{abstract}
Heterogeneous Fenton processes with solid catalysts have gained much attention for water and wastewater treatment in recent years. In the field of solid catalysts, zero valent iron (ZVI) is among the most applicable due to its stability, activity, pollutant degradation properties and environmental friendliness. The main limitation in the use of ZVI in heterogeneous Fenton systems is due to its deactivation in neutral and alkaline conditions, and Fenton-like processes have been developed to overcome this difficulty. In this review, the effect of solution $\mathrm{pH}$ on the ZVI-Fenton performance is discussed. In addition, the $\mathrm{pH}$ trend of $\mathrm{ZVI}$ efficiency towards contaminants removal is also considered in oxic solutions (i.e., in the presence of dissolved $\mathrm{O}_{2}$ but without $\mathrm{H}_{2} \mathrm{O}_{2}$ ), as well as in magnetic-field assisted Fenton, sono-Fenton, photo-Fenton and microwave-Fenton processes at different $\mathrm{pH}$ values. The comparison of the effect of $\mathrm{pH}$ on ZVI performance, taking into account both heterogeneous Fenton and different Fenton-like processes, can guide future studies for developing ZVI applications in water and wastewater treatment.
\end{abstract}

Keywords: heterogeneous Fenton; Fenton-like; Zero valent iron (ZVI); pH; wastewater treatment

\section{Introduction}

The Fenton reaction is widely accepted as a promising method for the degradation of organic and inorganic pollutants in water and wastewater [1-3]. This reaction takes place at room temperature and pressure, which helps reduce the treatment costs [2,4]. Moreover, the reaction is fast and requires easy-to-use reagents [5]. The Fenton process can be applied either to decontaminate wastewater so that it meets the standards for safe discharge into natural water bodies, or to minimize the effluent toxicity and enhance its biodegradability, thereby allowing for an efficient biological depuration in municipal wastewater treatment plants [6]. In the classic homogeneous Fenton process, strong oxidant species are primarily produced by reaction of $\mathrm{H}_{2} \mathrm{O}_{2}$ with iron ions $\left(\mathrm{Fe}^{2+}\right)$ in acidic conditions [7]. The homogeneous Fenton reaction has disadvantages because of catalyst consumption and sludge disposal, due to the need to adjust $\mathrm{pH}$ after treatment that causes iron precipitation [8-10].

To overcome these drawbacks, heterogeneous Fenton and Fenton-like processes have been developed by researchers over the past two decades. In the heterogeneous Fenton reaction, solid iron oxides $\left(\mathrm{Fe}_{2} \mathrm{O}_{3}, \mathrm{Fe}_{3} \mathrm{O}_{4}, \mathrm{FeO}, \mathrm{FeOOH}\right.$, etc. $)$ are used as Fenton catalysts with $\mathrm{H}_{2} \mathrm{O}_{2}$ [11,12]. Porous materials (e.g., activated carbon, clay, zeolite, multi-walled carbon nanotubes and polymers) can also be used as support for iron oxides $[13,14]$. In this case, the overall performance of the Fenton reaction can be increased due to the extra cooperation of the catalyst's support to adsorb pollutant molecules, and to initiate further pathways for radical generation and pollutants decomposition [13-15]. 
In Fenton-like processes, the generation of free radicals and the degradation of contaminants are carried out by using a catalyst together with magnetic field, ultrasound energy, ultraviolet radiation, microwave irradiation, other oxidizing reagents (e.g., persulfate), or a combination of them [16,17].

Among the catalysts used in heterogeneous Fenton and Fenton-like processes, zero-valent iron (ZVI) has attracted wide attention from researchers. ZVI is one of the most promising materials for water and wastewater treatment, due to its cost-effective and environmentally friendly production [18], non-toxicity [19], and ability to efficiently degrade or transform various pollutants such as halogenated compounds [20-22], nitrate [23], phosphate [24], polycyclic aromatic hydrocarbons [3,25], heavy metals [23,26,27], arsenic [28], dyes [6,29], and phenol $[4,30]$.

The main factors that affect the performance of ZVI towards contaminants removal in heterogeneous Fenton and Fenton-like processes can be divided into three categories: iron characteristics, operating conditions and solution chemistry [10-12]. Understanding the role of these factors is essential to develop the use of ZVI in Fenton and Fenton-like technology, and to adapt the engineering design to site-specific conditions. One of the most important operating parameters in the Fenton reaction is $\mathrm{pH}[31,32]$. The role of $\mathrm{pH}$ in controlling Fenton chemistry, free radicals generation, surface charge of catalyst and the amount of dissolved oxygen (DO) in solution has been proven extensively [20,21,33-36].

Although there are many researches on the preparation of ZVI and its application for the remediation of environmental pollutants, only a few review papers have briefly summarized the effect of $\mathrm{pH}$ as an independent parameter on the performance of ZVI in heterogeneous Fenton and Fenton-like processes $[9,26,30,37-39]$. Accordingly, this review comprehensively summarizes the effect of $\mathrm{pH}$ on the performance of ZVI for contaminants removal in heterogeneous Fenton and Fenton-like processes. Throughout this work, limitations of ZVI application in heterogeneous Fenton due to $\mathrm{pH}$ adjustment needs and the possibility to find alternative solutions are reviewed. In the first section, the general characteristics of ZVI and its use in the removal of contaminants from water and wastewater are discussed. A comprehensive discussion about the effect of $\mathrm{pH}$ on the efficiency of ZVI in heterogeneous Fenton processes is provided in the second section. The third section summarizes the effect of $\mathrm{pH}$ on different Fenton-like processes based on ZVI. At the end, conclusions and solutions are mentioned to manage the effect of $\mathrm{pH}$ on the heterogeneous ZVI-Fenton process aimed at pollutant degradation.

\section{Zero Valent Iron}

Zero valent iron (ZVI) is an effective reagent for the reduction of various environmental contaminants such as metal ions and halogenated organic compounds in water and wastewater, at ambient pressure and temperature $[36,40,41]$. The removal of contaminants by using ZVI is neither a purely chemical/electrochemical reduction, nor a purely physical adsorption process [10,42]. The process can in fact include complex interfacial pathways such as dissolution, adsorption, redox reaction and precipitation, which can occur simultaneously or sequentially on the iron surface [43-45]. ZVI alone is often used as an electron donor (reductant), but in the presence of $\mathrm{H}_{2} \mathrm{O}$, dissolved $\mathrm{O}_{2}$ and, most notably, $\mathrm{H}_{2} \mathrm{O}_{2}$ it becomes an effective source of strongly oxidizing species such as $\bullet \mathrm{OH}^{\circ}[9,46]$.

$\mathrm{ZVI}$ is not stable in ambient conditions and it converts to $\mathrm{Fe}^{2+}$ by reaction with water, dissolved oxygen, or both (Equations (1)-(2)) [10]. Moreover, it can easily get oxidized in the presence of $\mathrm{H}_{2} \mathrm{O}_{2}$ in the framework of the ZVI-Fenton process (Equation (3)) [47]. The generated ferrous ions from ZVI oxidation (Equations (1)-(3)) subsequently participate in the production of free radicals (mainly ${ }^{\bullet} \mathrm{OH}$, Equation (4)). These radicals are responsible for the degradation of organic and inorganic impurities in water and wastewater, causing their transformation and, possibly, organics mineralization (Equation (5)) [20,31,40].

$$
\begin{gathered}
\mathrm{Fe}^{0}{ }_{(\mathrm{s})}+2 \mathrm{H}_{2} \mathrm{O}_{(\mathrm{aq})} \rightarrow \mathrm{Fe}^{2+}{ }_{(\mathrm{aq})}+\mathrm{H}_{2(\mathrm{~g})}+2 \mathrm{OH}^{-}{ }_{(\mathrm{aq})} \\
\mathrm{Fe}^{0}{ }_{(\mathrm{s})}+\mathrm{O}_{2(\mathrm{~g})}+2 \mathrm{H}^{+} \rightarrow \mathrm{Fe}^{2+}{ }_{(\mathrm{aq})}+\mathrm{H}_{2} \mathrm{O}_{2(\mathrm{aq})}
\end{gathered}
$$




$$
\begin{gathered}
\mathrm{Fe}^{0}{ }_{(\mathrm{s})}+\mathrm{H}_{2} \mathrm{O}_{2(\mathrm{aq})} \rightarrow \mathrm{Fe}^{2+}{ }_{(\mathrm{aq})}+2 \mathrm{OH}^{-}{ }_{(\mathrm{aq})} \\
\mathrm{Fe}^{2+}{ }_{(\mathrm{aq})}+\mathrm{H}_{2} \mathrm{O}_{2(\mathrm{aq})} \rightarrow \mathrm{Fe}^{3+}{ }_{(\mathrm{aq})}+\mathrm{OH}^{-}{ }_{(\mathrm{aq})}+{ }^{\bullet} \mathrm{OH}
\end{gathered}
$$

$\bullet \mathrm{OH}+$ refractory compounds $\rightarrow \mathrm{H}_{2} \mathrm{O}+\mathrm{CO}_{2}+$ inorganic compounds

Rosales et al. have for instance synthesized ZVI from iron salts by using herbal extracts as reducing agents (rooibos, lemon verbena and camphor), to achieve Fenton degradation of dyes in wastewater [48]. From their results, synthesized rooibos-ZVI removed $90 \%$ of dyes in the Fenton reaction within $60 \mathrm{~min}$ [48]. Wu et al. have explored the activity of ZVI supported on kaolinite (ZVI-K) for the Fenton degradation of nitrobenzene [13]. The results indicated that ZVI-K could effectively remove nitrobenzene from water (92\% degradation under optimal experimental conditions) at $\mathrm{pH}$ values of up to 7.2. They proposed that in the first stage of the treatment, degradation was caused by nitrobenzene reduction by ZVI-K followed by heterogeneous Fenton. In the second stage the homogeneous Fenton reaction occurred in the presence of leached $\mathrm{Fe}$, with enhancement of degradation because of the synergistic effect between Fenton reaction and reduction by ZVI-K [13]. A study on cosmetic wastewater treatment with ZVI showed that, while COD removal $<15 \%$ was obtained by using $\mathrm{ZVI}$ or $\mathrm{H}_{2} \mathrm{O}_{2}$ alone, the ZVI-Fenton process $\left(\mathrm{ZVI}+\mathrm{H}_{2} \mathrm{O}_{2}\right)$ removed $84 \%$ of $\mathrm{COD}$ after $120 \mathrm{~min}$ [6]. Likewise, Segura et al. have applied the ZVI-Fenton process for the treatment of drug manufacturing plant wastewater [3], achieving $60 \%$ of TOC mineralization. Moreover, biodegradability of wastewater (in terms of the $\mathrm{BOD}_{5} / \mathrm{COD}$ ratio) increased to up to 0.35 from an initial value of 0.18 [3]. Naldoni et al. have studied the degradation of sodium dodecyl benzene sulfonate (DBS) and dodecylpyridinium chloride (DPC) using ZVI as a catalyst in the heterogeneous Fenton reaction [22]. The results showed $51 \%$ and $87 \%$ mineralization of, respectively, DBS and DPC by using ZVI [22].

In the absence of $\mathrm{H}_{2} \mathrm{O}_{2}$ the removal of water and wastewater contaminants by ZVI can occur through adsorption, reduction and co-precipitation, which is important especially in the case of heavy metals [42-44,49]. Moreover, ZVI can also produce $\mathrm{H}_{2} \mathrm{O}_{2}$ and trigger the Fenton reaction starting from dissolved $\mathrm{O}_{2}$ (reactions (1-4)), even in the absence of $\mathrm{H}_{2} \mathrm{O}_{2}$ addition. The use of ZVI in the sequestration process for contaminants removal from water and wastewater has been studied widely, exploiting adsorption, reduction and co-precipitation phenomena (e.g., $\mathrm{As}(\mathrm{V})$ [42], $\mathrm{Cr}(\mathrm{VI})$ and $\mathrm{Sb}$ (III) [43], $\mathrm{Cd}$ (II) [49], $\mathrm{Cu}^{2+}, \mathrm{CrO}_{4}{ }^{2-}$, 2-chloroacetophenone, 2,4,6-trinitrotoluene, carbon tetrachloride, trichloroethene [50], $\mathrm{NO}_{3}{ }^{-}$and $\left.\mathrm{NO}_{2}{ }^{-}[23,50]\right)$. An electron energy loss spectroscopy (EELS) analysis of $\mathrm{ZVI}$ has shown that surface-bonded $\mathrm{OH}$ groups $(\mathrm{Fe}-\mathrm{OH})$ are generated on the $\mathrm{ZVI}$ surface in the presence of water, and that they provide effective exchange sites for pollutants in the sequestration process [42]. The unique core-shell structure of ZVI includes a core of metallic iron, a shell of iron (II, III) oxides mixtures near the core, and an iron oxide layer (mostly Fe(III)) near the interface between the particles and the aqueous medium. The exact composition and characteristics of the iron oxide shell depends on the synthesis method and the environmental conditions [19]. The behavior of the ZVI shell is strongly related with the $\mathrm{pH}$ of the point of zero charge $\left(\mathrm{pH}_{\mathrm{PZC}}\right)$, which corresponds to the $\mathrm{pH}$ value at which the oxidized surface is uncharged [51]. At $\mathrm{pH}$ values lower than the $\mathrm{pH}_{\mathrm{PZC}}$, the ZVI surface is positively charged and it can adsorb anions simply via electrostatic attraction. In contrast, at $\mathrm{pH}>\mathrm{pH}$ PZC the negatively charged surface of ZVI attracts and adsorbs positively charged species, while at the same time one has electrostatic repulsion between anions and the ZVI surface $[42,50]$. It has been reported that the $\mathrm{pH}_{\mathrm{PZC}}$ of different iron oxides is typically in the range of 6-9.2 ( $\mathrm{pH}_{\mathrm{PZC}}$ of $\left.\alpha-\mathrm{Fe}_{2} \mathrm{O}_{3}=6.8-9.2, \mathrm{Fe}_{3} \mathrm{O}_{4} \approx 7.8, \alpha-\mathrm{FeO}(\mathrm{OH})=9, \gamma-\mathrm{Fe}_{2} \mathrm{O}_{3}=6.3\right)$ [43]. For instance, Cao and colleagues have reported that $\mathrm{ZVI}$ could adsorb more tetracycline at $\mathrm{pH}<5$ than at $\mathrm{pH} 10$ [52]. The authors attributed this result to the occurrence of high amounts of $\mathrm{Fe}_{2} \mathrm{O}_{3}, \mathrm{Fe}_{3} \mathrm{O}_{4}$ and $\mathrm{FeO}(\mathrm{OH})$ species on the $\mathrm{ZVI}$ surface at $\mathrm{pH}<5$, together with a strong electrostatic attraction between positively charged iron oxides and negatively charged tetracycline molecules [52].

The standard reduction potential of $\mathrm{ZVI}\left(\mathrm{Fe}^{2+} / \mathrm{Fe}^{0}\right)$ is $-0.44 \mathrm{~V}$, which is lower than that of many pollutants (e.g., $\mathrm{Cu}, \mathrm{Hg}, \mathrm{Pb}, \mathrm{Ni})[7,18]$. Therefore, several metals occurring as water-soluble ions can react with ZVI as an electron donor and precipitate, following reduction into insoluble metal 
forms. Ling and Zhang [42] and Miehr et al. [49] have also proposed that the removal of inorganic anions (e.g., $\mathrm{CrO}_{4}{ }^{2-}$ and $\mathrm{NO}_{3}{ }^{-}$) from water by using $\mathrm{ZVI}$, in the absence of hydrogen peroxide, involved anion adsorption to the oxide groups occurring on $\mathrm{Fe}^{0}$. In contrast, cations (e.g., $\mathrm{Cu}^{2+}$ ) were removed through reduction on comparatively oxide-free metal. A schematic of the reactions of ZVI with different types of contaminants is presented in Figure 1.

Yoshino et al. have studied the removal of $\mathrm{Cu}$ from acidic aqueous solutions by using ZVI [53], and batch experiments were carried out to investigate the effect of $\mathrm{pH}(2-5)$ on the $\mathrm{Cu}$ removal performance. The $\mathrm{pH}$ range was chosen to avoid formation and precipitation of $\mathrm{Cu}(\mathrm{OH})_{2}$ at $\mathrm{pH}>6$. Complete elimination of $1.57 \mathrm{mM} \mathrm{Cu}$ was obtained in $35,30,20$ and $40 \mathrm{~min}$ at an initial $\mathrm{pH}$ value of 2, 3, 4 and 5, respectively. The authors reported that the $\mathrm{pH}$ of the studied systems quickly increased to around 6 , except for the case of initial $\mathrm{pH} 2$. At initial $\mathrm{pH} 3-5$, the $\mathrm{pH}$ increase could be accounted for by fast iron dissolution accompanied by $\mathrm{H}^{+}$consumption. Due to higher initial $\left[\mathrm{H}^{+}\right]$, the same phenomenon at $\mathrm{pH}$ 2 only caused a slight $\mathrm{pH}$ increase from 2 to $2.3 \mathrm{after} 80 \mathrm{~min}$ of reaction. The authors suggested that the most important mechanism in $\mathrm{Cu}$ removal was the reduction of $\mathrm{Cu}^{2+}$ by $\mathrm{ZVI}$ in acidic conditions [53]. Qin et al. have suggested that the $\mathrm{Cu}^{2+}$ removal with $\mathrm{ZVI} / \mathrm{O}_{2}$ involved $\mathrm{Cu}^{2+}$ reduction by $\mathrm{Fe}^{0}$ at $\mathrm{pH} 4$ (Equation (6)), while the removal mechanism partially changed from reduction to adsorption under adequate dissolved oxygen values at $\mathrm{pH} 6$ [54].

$$
\mathrm{Fe}^{0}+\mathrm{Cu}^{2+} \rightarrow \mathrm{Fe}^{2+}+\mathrm{Cu}^{0}
$$

At $\mathrm{pH} 6$, the concentration of $\mathrm{Cu}^{2+}$ was also found to decrease because of deposition processes on the ZVI surface [54]. This hypothesis was confirmed by the XRD patterns of ZVI after reaction at $\mathrm{pH} 7$ that showed copper oxide peaks, whereas only peaks of $\mathrm{Cu}^{0}$ could be found in the corresponding XRD pattern of ZVI at $\mathrm{pH} 4$ [55]. According to Jiang et al., about $40 \% \mathrm{Cu}$ removal was obtained at $\mathrm{pH} 4$ after $120 \mathrm{~min}$, while negligible $\mathrm{Cu}$ removal was observed at $\mathrm{pH} 6$ at the same time scale [56]. The partial disagreement between different studies may suggest that the reductive pathway is more robust than that based on adsorption.
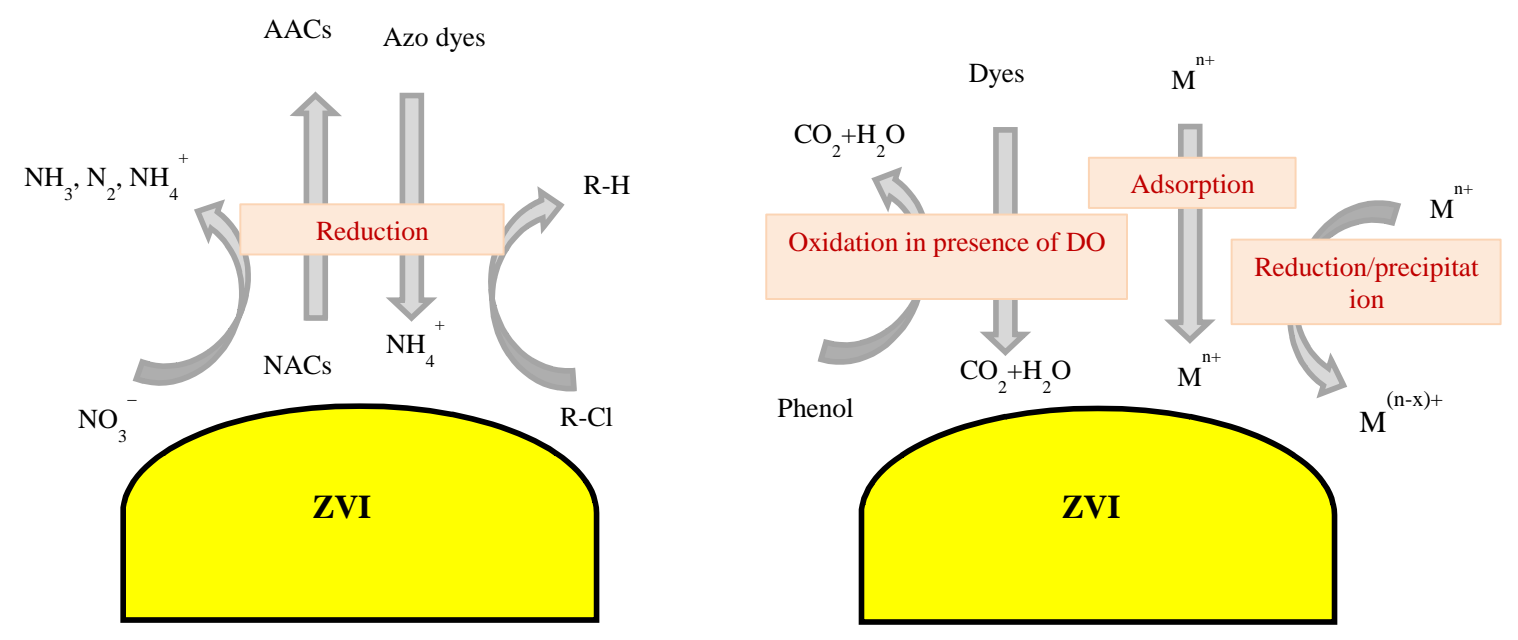

Figure 1. Schematic of pollutants removal by ZVI in the absence of $\mathrm{H}_{2} \mathrm{O}_{2}$. NACs = nitroaromatic compounds; AACs = aminoaromatic compounds.

Bae and Hanna have reported that high $\mathrm{pH}$ values (8-9) could improve the reduction rate of 4-nitrophenol when using low amounts of nano-ZVI $(0.010-0.075 \mathrm{~g} / \mathrm{L})$, in both un-buffered and buffered suspensions [57]. Their results also suggest that the contaminant reduction rate decreased at $\mathrm{pH}$ 6-7 in an un-buffered system, while buffered $\mathrm{pH}$ systems could preserve the ZVI particles against dissolution even at high $\mathrm{pH}$ values (8-9). These findings highlight the potential impacts of buffering agents on the performance of ZVI [57]. Alowitz and Scherer have shown that $\mathrm{Cr}(\mathrm{VI})$ could be removed from water in three steps: (1) adsorption of $\mathrm{Cr}(\mathrm{VI})$ to the iron oxides associated with 
$\mathrm{Fe}^{0}$; (2) reduction of $\mathrm{Cr}$ (VI) to $\mathrm{Cr}$ (III), and (3) co-precipitation of $\mathrm{Fe}(\mathrm{II} / \mathrm{III}) / \mathrm{Cr}$ (III) oxy-hydroxides [23]. In this case, alkaline $\mathrm{pH}$ can decrease the ZVI performance because it reduces iron solubility and generates a passive oxide layer [23]. On the other hand, different studies have shown that the decrease of $\mathrm{pH}$ has contrasting effects on the ZVI performance in the absence of $\mathrm{H}_{2} \mathrm{O}_{2}$. On the one side the acidic $\mathrm{pH}$ enhances iron corrosion, but on the other side the acceleration of ZVI corrosion decreases the sites available for contaminant adsorption $[53,54,56]$. Therefore, the optimal $\mathrm{pH}$ conditions for contaminants removal by using $\mathrm{ZVI}$ in the absence of $\mathrm{H}_{2} \mathrm{O}_{2}$ depend on the intrinsic characteristics of the contaminant and on the mechanism of its removal [23]. Comprehensive details of mechanism, kinetic parameters, benefits and application of ZVI in the presence and absence of $\mathrm{H}_{2} \mathrm{O}_{2}$ for water and wastewater treatment are already available (see [10,18,20,45,58-66], and references therein).

\section{Effect of pH on ZVI Performance}

\subsection{Heterogeneous Fenton Process. (ZVI-Fenton)}

In addition to the iron intrinsic properties, some operational parameters including $\mathrm{pH}[25,29]$, dissolved oxygen [67,68], iron dosage [24,69], iron pretreatment [70], ratio of $\mathrm{H}_{2} \mathrm{O}_{2} / \mathrm{Fe}^{0}[2,71]$ and temperature $[41,72,73]$ can also affect the performance of ZVI in the Fenton reaction, as well as the fate and transport of contaminants. Among the above-mentioned parameters, $\mathrm{pH}$ is one of the most important because it directly affects ZVI corrosion and the amount of dissolved oxygen in natural waters and industrial wastewaters $[25,29,39,74]$. Moreover, $\mathrm{pH}$ controls the generation of ions and free radicals in the Fenton reaction [62,74]. Donadelli et al. have studied the efficiency of the ZVI-Fenton removal of the azo dye acid black 1 at $\mathrm{pH} 3-5$, and the dye oxidation was significantly $\mathrm{pH}$-dependent $[62,75]$. The generation of highly reactive ${ }^{\bullet} \mathrm{OH}$ radicals was enhanced in acidic media, and it consequently enhanced the oxidation of azo bonds and aromatic structures [29]. At $\mathrm{pH} 3$ both dissolved $\mathrm{Fe}(\mathrm{II})$ and $\mathrm{Fe}(\mathrm{III})$ levels initially increased, although Fe(III) started decreasing after $10 \mathrm{~min}$ reaction time. The rapid consumption of $\mathrm{H}_{2} \mathrm{O}_{2}$ was probably responsible for the inhibition of the $\mathrm{Fe}(\mathrm{II})$ oxidation to Fe(III) (Equation (4)). At pH 5, the main iron species in solution was Fe(III) and the level of $\mathrm{Fe}(\mathrm{II})$ was at least two orders of magnitude below that observed at $\mathrm{pH}$ 3. As a result, both ZVI corrosion and the $\bullet \mathrm{OH}$ radicals production increased with decreasing $\mathrm{pH}$ [29].

Ling et al. have studied the degradation of acesulfame (a typical compound that is recalcitrant to biological water treatment) using ZVI-Fenton at $\mathrm{pH} 6.5$ [76]. To examine the mechanism of acesulfame decomposition, two suspensions at 500 and $5000 \mathrm{mg} / \mathrm{L}$ ZVI were prepared, and the degradation kinetics of acesulfame and $\mathrm{H}_{2} \mathrm{O}_{2}$ were compared with and without the presence of 2,2'-bipyridine (BPY) $5 \mathrm{mM}$. BPY can form a complex with $\mathrm{Fe}^{2+}{ }_{(\mathrm{aq})}$ and block the Fenton reaction, without interfering with the ZVI corrosion chemistry. The $\mathrm{H}_{2} \mathrm{O}_{2}$ degradation rates were not significantly affected by BPY in solution, while $5 \mathrm{mM}$ BPY almost completely inhibited the degradation of acesulfame. The suggested explanation was that $\mathrm{H}_{2} \mathrm{O}_{2}$ decomposition occurred primarily via reduction by ZVI, but acesulfame degradation was due to Fenton-generated $\bullet \mathrm{OH}$ radicals [76]. The cited authors also compared the efficiency of pre-oxidized ZVI, prepared by treating ZVI in $10 \mathrm{mM} \mathrm{H}_{2} \mathrm{O}_{2}$ and $1 \mathrm{mM} \mathrm{Cl}^{-}$for $90 \mathrm{~min}$, with untreated ZVI in the same conditions. The pre-oxidized ZVI decomposed $19 \%$ of the initial $\mathrm{H}_{2} \mathrm{O}_{2}$, compared to nearly $0 \%$ by untreated ZVI. The degradation of $\mathrm{H}_{2} \mathrm{O}_{2}$ by pre-oxidized ZVI was attributed to the heterogeneous Fenton reaction at the iron oxyhydroxide surface, thereby suggesting that pre-oxidized ZVI could be more active than untreated ZVI at neutral $\mathrm{pH}$ [76].

Zhang et al. have studied the ZVI-Fenton removal of norfloxacin [77], which is strongly $\mathrm{pH}$-dependent. The best degradation efficiency was observed at $\mathrm{pH} 3-4$, where almost $90 \%$ of norfloxacin was removed within $10 \mathrm{~min}$. By increasing the solution $\mathrm{pH}$ to around 6, the removal efficiency was reduced to $15 \%$ in $40 \mathrm{~min}$. Khan et al. have studied the effect of the initial pH (4-10) on azo-dye removal by ZVI-Fenton [78]. They have found that over $75 \%$ of the dye was eliminated in $250 \mathrm{~min}$ at $\mathrm{pH} 4$, while removal dropped down to $54 \%$ at $\mathrm{pH} 10$. It was concluded that degradation was enhanced in acidic and circumneutral conditions compared to alkaline ones, presumably because 
of higher ZVI corrosion and lower surface passivation at the lower $\mathrm{pH}$ values [78]. These results are in agreement with those of Harada et al. [47], who studied the effect of the solution pH (3-7) on the performance of micro- and nano-sized ZVI in wastewater treatment. The cited authors found a $56 \%$ decrease in ${ }^{\bullet} \mathrm{OH}$ production by increasing $\mathrm{pH}$ from 3 to 4 , and a further decrease when raising the $\mathrm{pH}$ to 5 [47]. Yuan et al. have shown that the COD removal efficiency of ZVI-Fenton increased rapidly (from $1.3 \%$ to $62.4 \%$ ) by decreasing the initial $\mathrm{pH}$ from 9 to 2.5 , while a further $\mathrm{pH}$ decrease from 2.5 to 2 had little effect on COD removal [79]. The lower $\mathrm{pH}$ values may favor the dissolution of passivating species (e.g., ferrous hydroxide) and other protective layers depositing on the surface of $\mathrm{Fe}^{0}$, thereby maintaining the number of active sites. The Fenton-like reactions in the presence of dissolved oxygen and without $\mathrm{H}_{2} \mathrm{O}_{2}$ could be enhanced as well at low $\mathrm{pH}$ [79]. A similar conclusion has been reached by Cheng et al., who also suggested that weaker and more selective oxidants like $\mathrm{FeO}^{2+}$ can be produced at higher $\mathrm{pH}$ (Equation (7)). The observed increase in $\mathrm{pH}$ as the reaction progressed might explain the fact that ZVI underwent gradual deactivation [80].

$$
\mathrm{Fe}^{2+}+\mathrm{H}_{2} \mathrm{O}_{2} \rightarrow \mathrm{FeO}^{2+}+\mathrm{H}_{2} \mathrm{O}
$$

Martins et al. have studied the ZVI-Fenton performance in the treatment of simulated and actual olive mill wastewater [4], analyzing the amount of Fe leached in solution at different $\mathrm{pH}$ values. In the $\mathrm{pH}$ interval 2-7 the maximum concentration of leached $\mathrm{Fe}^{2+}$ was observed at $\mathrm{pH} 3$, and a sharp $\left[\mathrm{Fe}^{2+}\right]$ drop was reported between $\mathrm{pH} 3$ and 4 [4]. Shen and coworkers have reported a decrease in the ZVI-Fenton performance at $\mathrm{pH}<3$, presumably due to a combination of factors (including the accumulation of $\mathrm{H}_{2}$ bubbles at the ZVI-solution interface) [81]. Katsoyiannis et al. have studied the effect of $\mathrm{pH}$ (3-11) on the ZVI-Fenton oxidation of As(III) in aerated water [82]. Their results showed that highly bioavailable As(III) $(1 \mathrm{mg} / \mathrm{L})$ could be completely converted into less bioavailable $\mathrm{As}(\mathrm{V})$ within $1 \mathrm{~h}$ by $0.1 \mathrm{~g} / \mathrm{L} \mathrm{ZVI}$ at $\mathrm{pH} 3$. In contrast, by increasing the initial $\mathrm{pH}$ to 5 and above, little dissolved $\mathrm{As}(\mathrm{V})$ could be detected even after $3 \mathrm{~h}$. These results may be attributed to the fact that, when increasing the $\mathrm{pH}$ values, $\mathrm{Fe}^{0}$ becomes unstable and reacts with water to form $\mathrm{Fe}^{2+}$. The $\mathrm{Fe}^{2+}$ ions may hydrolyze to $\mathrm{Fe}(\mathrm{OH})_{2}$ or be oxidized to $\mathrm{Fe}(\mathrm{III})$ by oxygen, without producing reactive species. [82]. Anyway, it is quite clear that the ZVI-Fenton performance for As(III) removal is $\mathrm{pH}$-dependent [82]. Likewise, Song and Carraway have reported that the removal of 1,1,2,2-tetrachloroethane by nanosized ZVI decreased when increasing the $\mathrm{pH}$ from 6.5 to 9.0 [83].

Overall, it can be concluded that the maximum efficiency of ZVI-Fenton toward pollutant degradation can be achieved at $\mathrm{pH} 3-4$, regardless of the target substrate [8]. The advanced explanation(s) may vary in different studies, but enhanced ZVI dissolution at acidic $\mathrm{pH}$ and the fact that maximum $\bullet \mathrm{OH}$ generation in the Fenton reaction takes place at $\mathrm{pH} 3$ can be regarded as reasonable hypotheses to account for these results $[9,46]$. Table 1 summarizes some illustrative works carried out on heterogeneous Fenton by using ZVI, together with their main results.

Table 1. Overview of works done in the area of heterogeneous Fenton using ZVI as catalyst.

\begin{tabular}{|c|c|c|c|c|}
\hline$\#$ & Target Compound & Experimental Conditions & Remarks & Ref. \\
\hline 1 & $\begin{array}{l}\text { Methylene Blue (MLB) } \\
\text { Methyl Orange (MO) }\end{array}$ & $\begin{array}{c}\text { ZVI: } 0.05 \mathrm{~g} \text {; dye volume: } \\
50 \mathrm{~mL} \text {; initial contaminant concentration: } \\
50 \mathrm{mg} / \mathrm{L} ; \mathrm{H}_{2} \mathrm{O}_{2}(10 \%): 5 \mathrm{~mL} ; \mathrm{pH}=3\end{array}$ & $\begin{array}{c}\text { Degradation percentages: } \\
\text { MLB: }>80 \% \text { in } 5 \text { min; MO: } 80 \% \text { in } 1 \mathrm{~h} .\end{array}$ & [84] \\
\hline 2 & Orange II & $\begin{array}{c}\text { ZVI: } 0.02 \mathrm{~g} / \mathrm{L} \text {; initial contaminant } \\
\text { concentration: } 58 \mathrm{mg} / \mathrm{L} ; \\
\mathrm{H}_{2} \mathrm{O}_{2}(28 w / w \%) ; \mathrm{pH}=2-9\end{array}$ & $\begin{array}{c}39,52,38,22,16,16,11 \\
\text { and } 10 \% \text { removal in } 10 \text { min at initial } \mathrm{pH} \\
\text { value } 2,3,4,5,6,7,8,9, \text { respectively. }\end{array}$ & [85] \\
\hline 3 & $\begin{array}{l}\text { Amoxicillin (AMX) } \\
\text { COD }\end{array}$ & $\begin{array}{c}\text { ZVI: } 500 \mathrm{mg} / \mathrm{L} ; \mathrm{AMX} 50 \mathrm{mg} / \mathrm{L} ; \\
\mathrm{H}_{2} \mathrm{O}_{2} 6.6 \mathrm{mM} ; \mathrm{pH}=3 \text {; temperature } 30^{\circ} \mathrm{C}\end{array}$ & $\begin{array}{c}\text { 86.5\% removal of AMX; } \\
71.2 \% \text { of COD removal in } 25 \mathrm{~min} .\end{array}$ & [86] \\
\hline 4 & Norfloxacin (NOR) & $\begin{array}{l}\text { ZVI: } 100 \mathrm{mg} / \mathrm{L} ; \mathrm{H}_{2} \mathrm{O}_{2} \text { concentration: } \\
20 \mathrm{mmol} / \mathrm{L} ; \mathrm{pH}=4 \text {; temperature } 35^{\circ} \mathrm{C}\end{array}$ & $90 \%$ NOR removal in $40 \mathrm{~min}$. & {$[77]$} \\
\hline 5 & 4-chloro-3-methyl phenol (CMP) & $\begin{array}{l}\text { ZVI: } 0.5 \mathrm{~g} / \mathrm{L} ; \mathrm{CMP} \text { concentration: } 0.7 \mathrm{mM} ; \\
\qquad \mathrm{H}_{2} \mathrm{O}_{2}: 3 \mathrm{mM} ; \mathrm{pH}=3-6\end{array}$ & $\begin{array}{l}99 \% \text { CMP removal at } \mathrm{pH} \text { of } 3 \text { and } 6 \text { in } \\
1 \text { and } 15 \mathrm{~min} \text {, respectively. }\end{array}$ & [87] \\
\hline
\end{tabular}


Table 1. Cont.

\begin{tabular}{|c|c|c|c|c|}
\hline$\#$ & Target Compound & Experimental Conditions & Remarks & Ref. \\
\hline 6 & Pentachlorophenol (PCP) & $\begin{array}{l}\text { ZVI: } 15 \mathrm{mg} ; \mathrm{PCP} \text { concentration: } 50 \mathrm{mg} / \mathrm{L} ; \\
\mathrm{H}_{2} \mathrm{O}_{2}: 0.5 \% ; \mathrm{pH}=3 \text {; temperature } 30^{\circ} \mathrm{C}\end{array}$ & $90 \%$ PCP removal in $30 \mathrm{~min}$. & [80] \\
\hline 7 & 4-chlorophenol (4CP) & $\begin{array}{l}\text { ZVI: } 1 \mathrm{~g} / \mathrm{L} ; 4 \mathrm{CP} \text { concentration: } 100 \mathrm{mg} / \mathrm{L} ; \\
\quad \mathrm{H}_{2} \mathrm{O}_{2}: 0.5 \% \text {; temperature } 20{ }^{\circ} \mathrm{C}\end{array}$ & $\begin{array}{c}100 \% 4 \mathrm{CP} \text { degradation at } \mathrm{pH} \text { of } 3 \text { and } \\
4 \text { in } 8 \text { and } 30 \text { min, respectively. } \\
12.5 \% \mathrm{H}_{2} \mathrm{O}_{2} \text { decomposition at } \mathrm{pH} 6.5 \text { and } \\
70 \% \text { at } \mathrm{pH} 5 \text { in the same conditions. }\end{array}$ & [88] \\
\hline 8 & $\mathrm{Cr}$ (VI), TOC, COD, Phenol & $\begin{array}{c}\mathrm{ZVI} / \mathrm{H}_{2} \mathrm{O}_{2}(w / w): 0.5,0.75,1,1.25,1.5 \\
\mathrm{H}_{2} \mathrm{O}_{2} / \mathrm{COD}(w / w): 0.5,0.7,1 ; \mathrm{pH}=2,2.5 \\
\text { 3, 3.7, 5; temperature: } 15,20,30,35^{\circ} \mathrm{C}\end{array}$ & $\begin{array}{c}\text { At } \mathrm{H}_{2} \mathrm{O}_{2} / \mathrm{COD}(w / w): 0.5, \mathrm{ZVI} / \mathrm{H}_{2} \mathrm{O}_{2} \\
(w / w): 0.75 \text { and } \mathrm{pH}=3 \text {, there was a total } \\
\text { removal of } \mathrm{Cr}(\mathrm{VI}) \text { as well as TOC, COD } \\
\text { and phenols degradation efficiency up to } \\
70,73 \text { and } 88 \% \text {, respectively. }\end{array}$ & [89] \\
\hline 9 & Methyl tert-butyl ether (MTBE) & $\begin{array}{c}\text { ZVI: } 250 \mathrm{mg} / \mathrm{L} ; \mathrm{MTBE} \text { concentration: } \\
1000 \mu \mathrm{g} / \mathrm{L} ; \mathrm{H}_{2} \mathrm{O}_{2}: \text { MTBE (molar } \\
\text { ratio) }=220: 1 ; \mathrm{pH}=3,4,7\end{array}$ & $\begin{array}{l}\text { MTBE removal of } 99,96,72 \% \text { at } \mathrm{pH} \\
\text { values of } 4,7,3 \text { respectively in } 24 \mathrm{~h} \text {. }\end{array}$ & [90] \\
\hline 10 & Phenol & $\begin{array}{l}\text { ZVI: } 1 \mathrm{~g} / \mathrm{L} ; \text { phenol concentration: } \\
100 \mathrm{mg} / \mathrm{L} ; \mathrm{H}_{2} \mathrm{O}_{2} \text { concentration: } 1,5 \\
\text { 10, 25, 50, } 100 \mathrm{mM} ; \mathrm{pH}=2.5 .\end{array}$ & $\begin{array}{l}80 \% \text { and } 100 \% \text { phenol degradation by } \\
5 \text { and } 10 \mathrm{mM} \mathrm{H}_{2} \mathrm{O}_{2} \text {, respectively. }\end{array}$ & [91] \\
\hline
\end{tabular}

\subsection{Fenton-Like Processes}

As suggested above, the removal of contaminants by the ZVI-Fenton reaction may be limited to acidic conditions [22,82,92]. To overcome this problem, Fenton-like processes have been developed [93]. Depending on the site of the catalytic reactions, these can be classified into heterogeneous Fenton-like and homogeneous Fenton-like processes [46]. In a heterogeneous Fenton-like reaction, $\mathrm{Fe}^{2+}$ is replaced by a solid iron catalyst. In contrast, homogeneous Fenton-like processes include a combination of other metal ion(s)/metal ion-organic ligand complexes and $\mathrm{H}_{2} \mathrm{O}_{2}$ [31,94]. However, a more common classification of Fenton-like processes is based on the generation method of $\bullet \mathrm{OH}$ radicals. On this basis, Fenton-like techniques include magnetic field assisted-Fenton, sono-Fenton, photo-Fenton, microwave-Fenton, and the use of oxic solutions or other oxidizing reagents (e.g., persulfate) in addition to the catalyst $[16,17,67,75]$. This latter definition of a Fenton-like process is used in the present review paper. The present section discusses the effect of $\mathrm{pH}$ on the performance of different Fenton-like processes that use ZVI as catalyst.

\subsubsection{ZVI in Oxic Solutions}

These processes make use of $\mathrm{ZVI}+\mathrm{O}_{2}$ to generate the Fenton reactants (see Equations (1), (2) and (4), avoiding the addition of $\mathrm{H}_{2} \mathrm{O}_{2}$. Yamaguchi et al. have studied the effect of $\mathrm{pH}$ on the efficiency of a $\mathrm{ZVI} / \mathrm{Cu}$ bimetallic catalyst for the Fenton-like treatment of oxic wastewater [25]. The cited authors reported that both dissolution of deposited $\mathrm{Cu}$ and $\mathrm{ZVI}$ corrosion actively occurred at $\mathrm{pH} 3$, which subsequently led to the in-situ production of Fenton reagents (i.e., $\mathrm{Fe}^{2+}$ and $\mathrm{H}_{2} \mathrm{O}_{2}$ ) and to ${ }^{\bullet} \mathrm{OH}$ radical generation [25]. Guan et al. have suggested that the $\mathrm{ZVI} / \mathrm{O}_{2}$ system is not a useful remediation method, due to the low yields of oxidizing species that can react with organic compounds [93]. In contrast, Joo et al. have studied the degradation of the carbothiolate herbicide molinate in oxic solutions using nano-ZVI [95], and reported over $60 \%$ molinate degradation at $\mathrm{pH} 8.1$ (150 min reaction time, $21.4 \mathrm{mM} \mathrm{ZVI).} \mathrm{The} \mathrm{degradation}$ percentage reached $65 \%$ at $\mathrm{pH} 4$, under otherwise identical conditions as those used at $\mathrm{pH} 8.1$ [95]. At $\mathrm{pH}$ 8.1, accumulation of $\mathrm{Fe}^{2+}$ in solution was insignificant due to its rapid oxidation by $\mathrm{H}_{2} \mathrm{O}_{2}$. By decreasing the initial $\mathrm{pH}$ value from 8.1 to 4 the concentration of ferrous iron decreased more slowly over time, as a consequence of the balance between released $\mathrm{Fe}^{2+}$ from the $\mathrm{Fe}^{0}$ surface, and the subsequent $\mathrm{Fe}^{2+}$ oxidation to $\mathrm{Fe}(\mathrm{III})$ species by $\mathrm{H}_{2} \mathrm{O}_{2}$. Interestingly, the time trend of molinate degradation was relatively similar at both $\mathrm{pH} 4$ and 8.1. The cited authors proposed that the continuous generation of fresh reactants $\left(\mathrm{Fe}^{2+}\right.$, oxygen species, ferryl species and $\left.\mathrm{H}_{2} \mathrm{O}_{2}\right)$ accounted for the process effectiveness at high $\mathrm{pH}$, which was limited by $\mathrm{Fe}^{0}$ availability [95]. It could be concluded that the slow release/formation of key reactants and the continuing effectiveness in contaminant degradation could extend the $\mathrm{pH}$ range of the possible applications of ZVI-mediated oxidative processes [73,95]. 


\subsubsection{Magnetic-Field Assisted Fenton Process}

Zhou et al. have applied magnetic field (MF) as well as ZVI/EDTA for the removal of diclofenac from wastewater [96]. They reported that acidic conditions were more favorable to contaminant removal, but the MF/ZVI/EDTA system could effectively decompose diclofenac in the $\mathrm{pH}$ range of 4 to 7 [96]. Different studies have shown that application of magnetic field together with EDTA could accelerate pitting corrosion on the disclosed fresh $\mathrm{Fe}^{0}$ sites, in neutral or even alkaline systems $[96,97]$. The mechanism of contaminant removal by ZVI/EDTA at acidic $\mathrm{pH}$ involves the formation of complexes between EDTA and Fe ions (Equation (8)), together with the reaction of the $\mathrm{Fe}^{\mathrm{II}}$ EDTA complex with soluble oxygen (Equation (9)) to yield $\mathrm{O}_{2}{ }^{\bullet-}$. The latter produces $\mathrm{H}_{2} \mathrm{O}_{2}$ by disproportionation, which finally gives $\bullet \mathrm{OH}$ that induces pollutant degradation.

$$
\begin{gathered}
\mathrm{Fe}^{\mathrm{III}} \mathrm{EDTA}+\mathrm{e}^{-} \rightarrow \mathrm{Fe}^{\mathrm{II}} \text { EDTA } \\
\mathrm{Fe}^{\mathrm{II}} \mathrm{EDTA}+\mathrm{O}_{2} \rightarrow \mathrm{Fe}^{\mathrm{III}} \mathrm{EDTA}+\mathrm{O}_{2}^{\bullet-}
\end{gathered}
$$

Zhou and colleagues have proposed that the magnetic field does not change the mechanism of diclofenac removal by ZVI/EDTA, but that it enhances iron corrosion in a broad $\mathrm{pH}$ range (4 to 7) [96]. Pan et al. have studied the degradation of orange $\mathrm{G}$ by using $\mathrm{ZVI} / \mathrm{H}_{2} \mathrm{O}_{2}$ at different $\mathrm{pH}$ values (3-9) in a salty wastewater [98]. They have found that the contaminant removal rate decreased by $50 \%$ when the initial $\mathrm{pH}$ was increased from 3 to 9 . To enhance degradation, the cited authors examined the efficiency of $\mathrm{MF} / \mathrm{ZVI} / \mathrm{H}_{2} \mathrm{O}_{2}$ in the same conditions. Results showed that the degradation percentage of orange $\mathrm{G}$ at $\mathrm{pH} 9$ after 60 min reaction time was increased from $16.4 \%$ with $\mathrm{ZVI} / \mathrm{H}_{2} \mathrm{O}_{2}$, to $32.7 \%$ with $\mathrm{MF} / \mathrm{ZVI} / \mathrm{H}_{2} \mathrm{O}_{2}$ [99]. Liang et al. [100] and Feng et al. [101] have reported similar results for the removal of chromate and selenite using ZVI and magnetic field. In the presence of a magnetic field, free electrons and $\mathrm{Fe}^{2+}$ ions are continually released from reactive anode $\mathrm{Fe}^{0}$ sites, and then they are transferred to the surface of $\mathrm{Fe}_{\mathrm{x}} \mathrm{O}_{\mathrm{y}}$ cathode sites to yield $\bullet \mathrm{OH}$ for the oxidation of contaminant molecules. Additionally, reductive adsorption of contaminants could directly occur on the $\mathrm{Fe}^{0}$ surface. Some studies have reported that in MF/ZVI systems, ${ }^{\bullet} \mathrm{OH}$ radicals could be generated at anodic sites upon oxidation of water even at neutral and alkaline $\mathrm{pH}$ values $[97,99,100]$.

Xiong et al. have studied the effect of $\mathrm{pH}(3-10)$ in a persulfate/ZVI system coupled with magnetic field for the removal of orange G [100]. The application of the magnetic field enhanced orange G degradation by $5-28$ folds in the $\mathrm{pH}$ range $3-9$. However, at $\mathrm{pH} 10$ the removal of the contaminant was significantly inhibited. In this case, the formation of a passive iron oxide layer on the ZVI surface would slow down $\mathrm{Fe}^{0}$ corrosion [100]. Still, in the other conditions the solution $\mathrm{pH}$ was not a limiting factor for the ZVI performance in the presence of a magnetic field. Moreover, the magnetic field could increase the generation of sulfate radicals and of $\mathrm{Fe}^{3+}$ by accelerating the release of $\mathrm{Fe}^{2+}$ from the ZVI surface, thereby increasing the rate of the reaction between $\mathrm{Fe}^{2+}$ and persulfate. The generated sulfate radicals could degrade orange $\mathrm{G}$, while the $\mathrm{Fe}^{3+}$ hydrolysis would yield $\mathrm{H}^{+}$and cause a sharp $\mathrm{pH}$ drop. The $\mathrm{pH}$ decrease could further increase the ZVI corrosion, thereby amplifying the influence of the magnetic field [100]. Several studies have in fact demonstrated that the main synergistic role of the magnetic field in the system operates through increased surface dissolution and corrosion of ZVI, which occurs together with a decrease in solution $\mathrm{pH}[97,99,101]$. Due to enhanced dissolution, the MF-ZVI-Fenton system can still be operational at neutral and alkaline $\mathrm{pH}$ values. A schematic of the MF-ZVI-Fenton process is shown in Figure 2.

\subsubsection{Sono-Fenton Process}

Man and coworkers have used ultrasound and a ZVI/EDTA/air system (no $\mathrm{H}_{2} \mathrm{O}_{2}$ added) to remove polycyclic aromatic hydrocarbons (PAHs) from textile dyeing sludge, at different initial $\mathrm{pH}$ values (3-9) [99]. The reported PAH removal efficiencies showed a slight difference by changing $\mathrm{pH}$ from 3 to 6 , but they declined significantly by further increasing $\mathrm{pH}$ to 9 because of limited formation 
of $\mathrm{Fe}^{2+}$ and $\mathrm{Fe}^{3+}$. The reported results suggest that the ultrasound/ZVI/EDTA/Air system could be used effectively in the acidic and neutral $\mathrm{pH}$ range. The cited authors suggested that the role of ultrasound in the Fenton process was both physical and chemical, based on the phenomenon of acoustic cavitation [99].

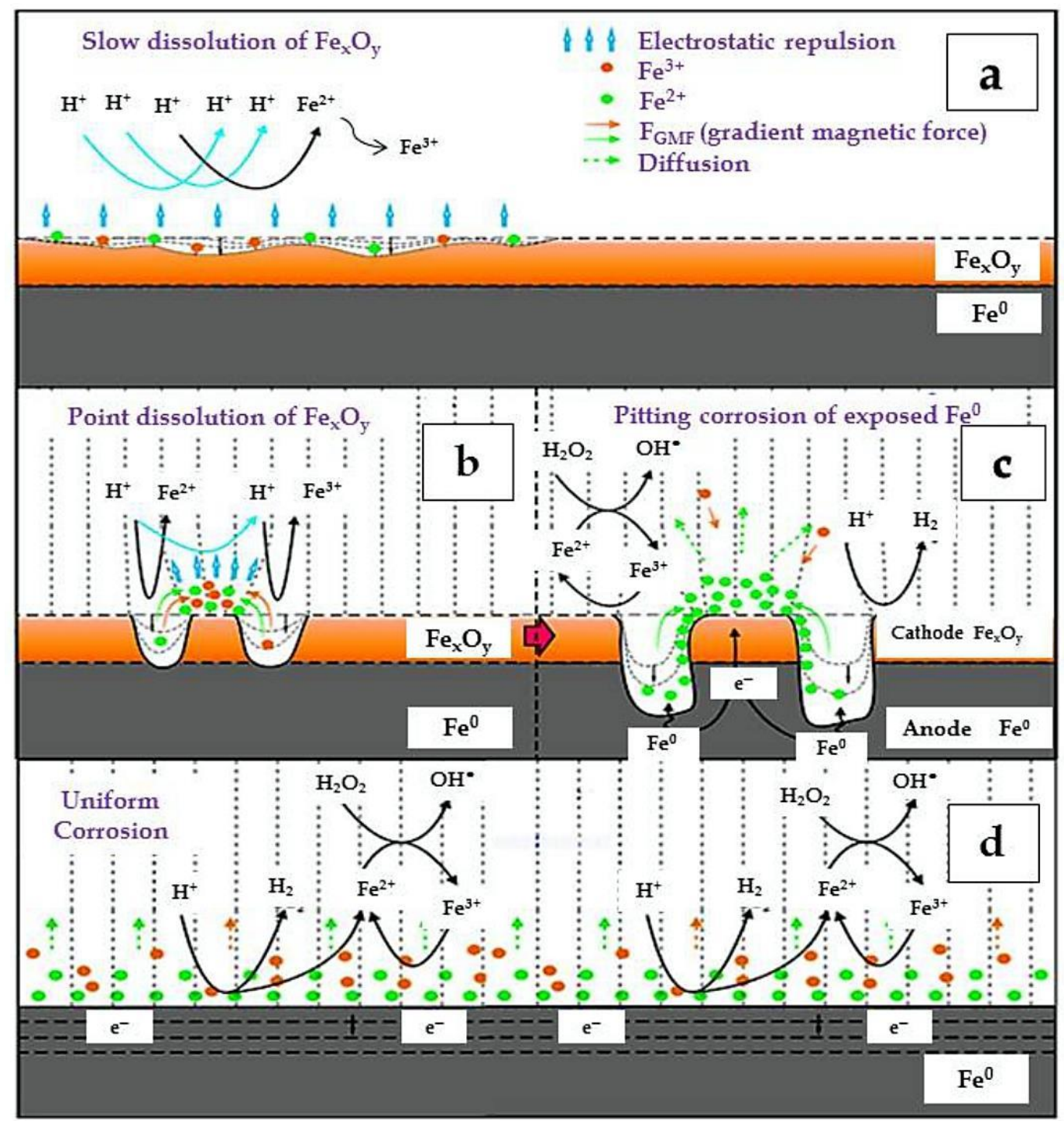

Figure 2. Schematic of a typical MF-ZVI-Fenton system. (a): Slow $\mathrm{Fe}_{\mathrm{x}} \mathrm{O}_{\mathrm{y}}$ dissolution in the ZVI-Fenton system; (b): rapid point dissolution of $\mathrm{Fe}_{\mathrm{x}} \mathrm{O}_{\mathrm{y}}$ in the presence of magnetic field followed by (c): pitting corrosion of the exposed $\mathrm{Fe}^{0}$ sites and (d): uniform corrosion of the ZVI surface. Reproduced with permission from Reference [97].

Cavitation could generate strong convection in aqueous media, because of ultrasonic vibration, micro-turbulence, and shockwaves. Ultrasounds can in fact produce large numbers of micro-bubbles in water, which grow and then collapse. Temperature and pressure inside adiabatically collapsing micro-bubbles can rise within a microsecond to levels of 4000-15,000 K and 100-5000 bar, respectively. As a result, hydroxyl radicals are generated from water vapor decomposition [34,99]. Man et al. proposed that in the ultrasound/ZVI/EDTA/Air system, $\mathrm{O}_{2}$ activation could occur at the ZVI surface or near it, with significant generation of $\mathrm{H}_{2} \mathrm{O}_{2}$ and free radicals that would then oxidize the contaminants. At the same time, a fraction of the contaminants could be removed from the solution upon adsorption onto the ZVI surface [99]. Because the PAH molecules are hydrophobic, they have high tendency to adsorb onto or around the ZVI surface. Therefore, PAHs might be removed more 
quickly by ultrasound/ZVI/EDTA/Air than other less hydrophobic organic compounds under the same conditions [99].

Fu et al. have studied the effect of $\mathrm{pH}$ (3-9) on selenite removal using ultrasound/ZVI. They found a definite $\mathrm{pH}$ dependence [34], which could be attributed to the $\mathrm{pH}$ trend of selenite speciation coupled with ZVI surface charge and Fenton reactivity. At $\mathrm{pH} \geq 3$ the dominant species of selenite is $\mathrm{HSeO}_{3}{ }^{-}$, whereas $\mathrm{SeO}_{3}{ }^{2-}$ ions are formed at $\mathrm{pH} \geq 8$. Selenite removal decreased at $\mathrm{pH} \geq 8$, due to the decline in both Fenton and adsorption processes. In fact, one can expect limited generation of $\bullet^{\bullet} \mathrm{OH}$ radicals and a lower ${ }^{\bullet} \mathrm{OH}$ oxidation potential under alkaline conditions. Moreover, the negative surface charge of $\mathrm{ZVI}$ at $\mathrm{pH} \geq 8.2$ inhibits adsorption of negative $\mathrm{HSeO}_{3}{ }^{-}$and $\mathrm{SeO}_{3}{ }^{2-}[34,100]$.

Taha et al. [101] and Weng et al. [5] have suggested that ultrasound radiation could not affect the production of $\mathrm{Fe}^{2+}$ by ZVI at $\mathrm{pH}$ above 4, due to the protection of the ZVI surface by a layer of iron oxides. The different findings of the two latter studies [5,101] compared to the other ones $[34,100]$ could be attributed to the fact that Taha et al. [101] and Weng et al. [5] have used lower ultrasound intensity ( 0.12 vs. $\left.0.3-1.08 \mathrm{~W} / \mathrm{cm}^{3}\right)$, lower degradation time ( $\left.10 \mathrm{vs} .90 \mathrm{~min}\right)$ and lower amount of ZVI catalyst ( 0.5 vs. $5-30 \mathrm{~g} / \mathrm{L})$. It can be concluded that ultrasound radiation might extend the applicable $\mathrm{pH}$ range of Fenton-like processes to near-alkaline conditions, provided that sufficiently high ultrasound intensity and ZVI loading is used. A schematic of a typical ultrasound-ZVI-Fenton system is illustrated in Figure 3.

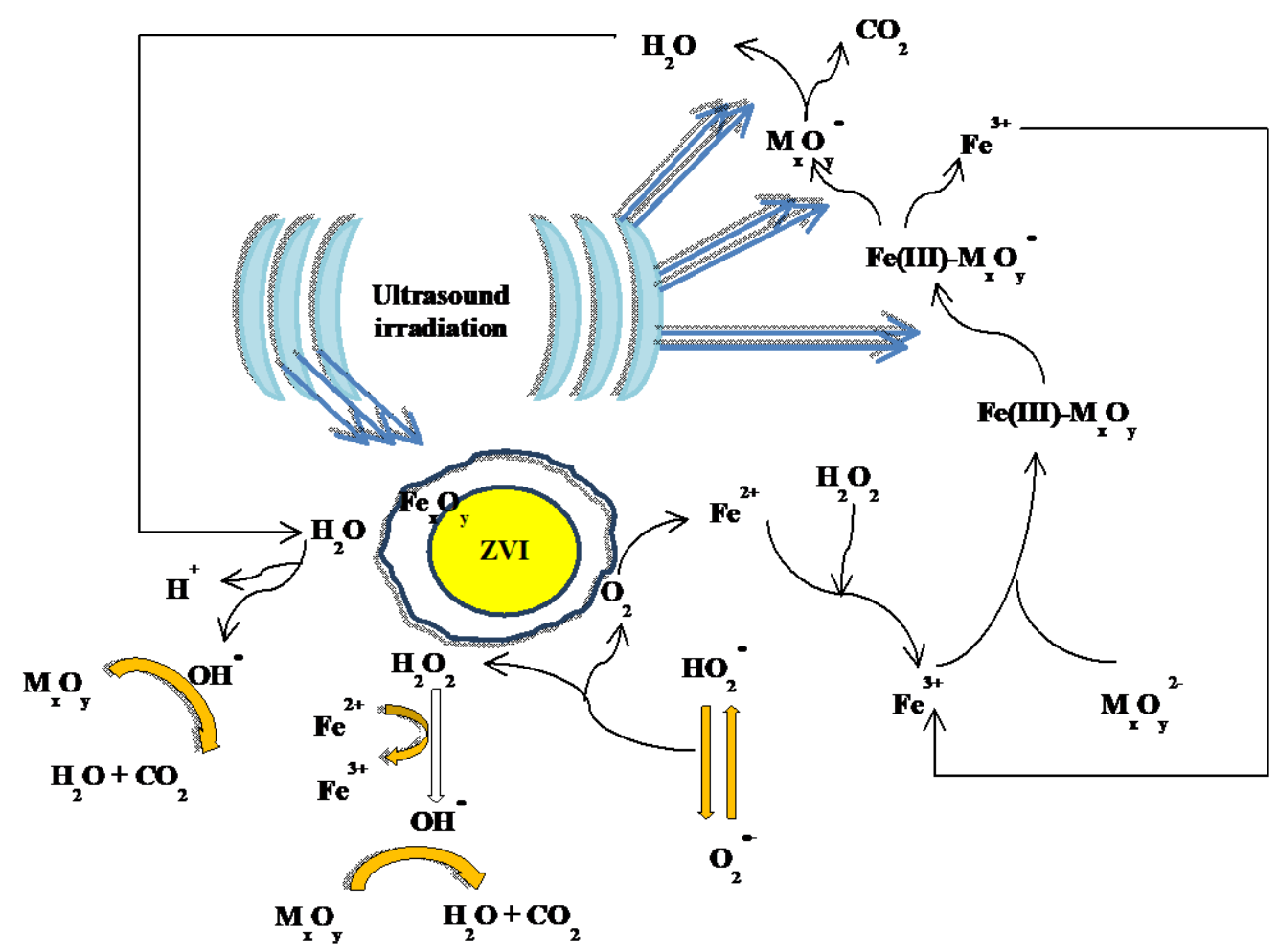

Figure 3. Schematic of a typical ultrasound-ZVI-Fenton mechanism (note that $\mathrm{M}_{\mathrm{x}} \mathrm{O}_{\mathrm{y}}$ represents a generic organic pollutant).

\subsubsection{Photo-Fenton Process}

The Fenton reaction is often more efficient under irradiation conditions (photo-Fenton) than in the dark, because the photolysis of Fe(III) compounds yields Fe(II) and enhances Fe(III) recycling. Therefore, more $\mathrm{Fe}$ (II) can react with $\mathrm{H}_{2} \mathrm{O}_{2}$ and yield reactive transient species such as ${ }^{\bullet} \mathrm{OH}$.

Santos-Juanes et al. have used a ZVI/ $\mathrm{H}_{2} \mathrm{O}_{2} / \mathrm{UV}$ system and have reported a decrease with $\mathrm{pH}$ of the degradation percentage of p-nitrobenzoic acid, from $70 \%$ at $\mathrm{pH} 3.5$ to $<10 \%$ at $\mathrm{pH} \geq 5$ [1]. They have proposed that acidic $\mathrm{pH}$ and the presence of $\mathrm{H}_{2} \mathrm{O}_{2}$ could favor the oxidative photo-Fenton 
process, whereas at mild $\mathrm{pH}$ (especially if $\mathrm{H}_{2} \mathrm{O}_{2}$ was not added) the Fenton reaction was inhibited and the prevailing pathway was substrate reduction by ZVI [1]. Minella and coworkers have reported that $\mathrm{ZVI}$ was inactive in a UV-A/ $\mathrm{H}_{2} \mathrm{O}_{2}$ system for the degradation of phenol at $\mathrm{pH}>5$, but the same system in the dark was already inactive at $\mathrm{pH}>4$ [101]. Rahim Pouran et al. have found that the ZVI efficiency in the photo-Fenton process decreased at $\mathrm{pH}>4$, due to precipitation of ferric hydroxide that reduced radiation transmission [102]. Likewise, Grcic et al. have shown that the specific (surface-area normalized) reaction rate constant for dye oxidation in wastewater using a UV-C/ZVI-Fenton system was $0.020,0.019$ and $0.012 \mathrm{~L} \mathrm{~min}^{-1} \mathrm{~m}^{-2}$ at $\mathrm{pH} 3.5,4$ and 5, respectively [7]. They suggested that at $\mathrm{pH}$ $2.5-5$ the generation of $\bullet \mathrm{OH}$ radicals could take place through photolysis of the $[\mathrm{Fe}(\mathrm{OH})]^{2+}$ complexes (Equation (10)), in addition to the typical Fenton reaction (Equation (11)) [103].

$$
\begin{gathered}
{[\mathrm{Fe}(\mathrm{OH})]^{2+}+h v \rightarrow \mathrm{Fe}^{2+}+{ }^{\bullet} \mathrm{OH}} \\
\mathrm{Fe}^{2+}+\mathrm{H}_{2} \mathrm{O}_{2} \rightarrow[\mathrm{Fe}(\mathrm{OH})]^{2+}+{ }^{\bullet} \mathrm{OH}
\end{gathered}
$$

Because $\mathrm{Fe}(\mathrm{II})$ is oxidized to $\mathrm{Fe}(\mathrm{III})$ in the reaction with $\mathrm{H}_{2} \mathrm{O}_{2}$ (Equation (11)), the cycle can continue [103]. This cycle is anyway restricted in neutral and alkaline $\mathrm{pH}$ conditions due to two reasons: (1) generation of less reactive species like ferryl as the $\mathrm{pH}$ increases, instead of highly active - $\mathrm{OH}$ radicals; (2) limited leaching of Fe species from oxide coating surfaces at $\mathrm{pH}>5$, which prevents the occurrence of photoactive $[\mathrm{Fe}(\mathrm{OH})]^{2+}[101]$. It can thus be concluded that the $\mathrm{ZVI} / \mathrm{H}_{2} \mathrm{O}_{2} / \mathrm{UV}$ system may be efficient up to circumneutral conditions, but not at alkaline $\mathrm{pH}$. However, some studies have shown that a process set-up with physically separated compartments of ZVI corrosion and photo-Fenton reaction could enhance the degradation of hardly oxidized contaminants, even at neutral $\mathrm{pH}$ values [1]. In the first stage of such systems, contaminants are removed via adsorption onto the ZVI surface or are modified to produce more labile compounds, which are then oxidized in the subsequent photo-Fenton stage. In addition, iron cations leached to the solution in the first stage could further participate in the photo-Fenton process. Moreover, in a combined $\mathrm{ZVI} / \mathrm{H}_{2} \mathrm{O}_{2} / \mathrm{UV}$ system, light scattering could occur due to the presence of the solid catalyst and it would decrease the amount of available photons for photochemical reactions [1]. An illustration of the photo-Fenton mechanism using iron-based materials is shown in Figure 4.

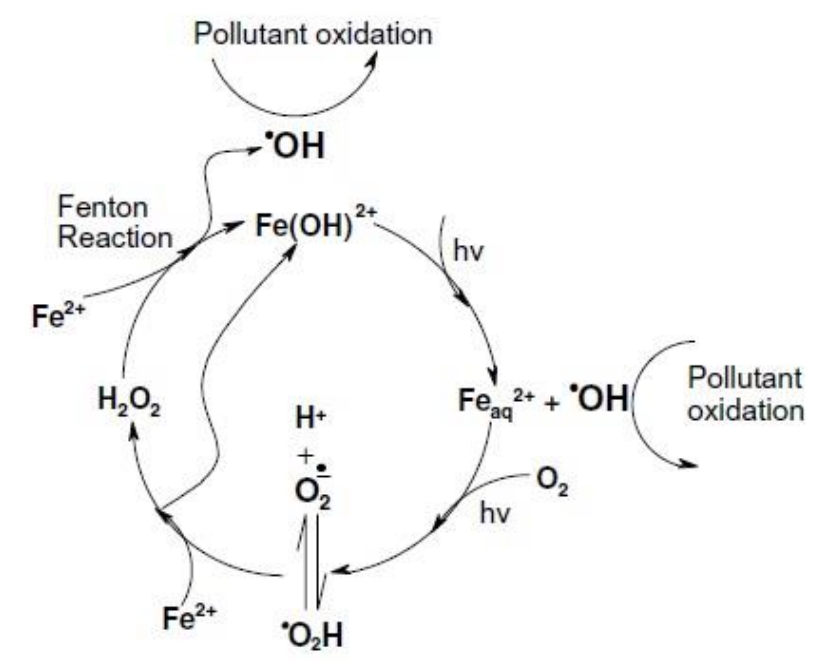

Figure 4. Model of photo-Fenton mechanism using iron-based catalysts. Reproduced with permission from Reference [104].

\subsubsection{Microwave-Assisted Fenton-Like Process}

There are few studies in the area of microwave-assisted Fenton reaction using ZVI as a catalyst. Chen et al. have implemented microwave irradiation (MW) coupled with $\mathrm{ZVI} / \mathrm{H}_{2} \mathrm{O}_{2}$ to treat 
concentrated landfill leachate [17]. According to BET analysis, the used ZVI had average pore size of 2-30 $\mathrm{nm}$ and specific surface area of $0.844 \mathrm{~m}^{2} / \mathrm{g}$ before the reaction. The average pore size changed to $2-50 \mathrm{~nm}$ after the reaction, and the authors proposed that microwave irradiation could modify the ZVI surface to produce larger pores, which are more efficient for degradation processes [17]. Zhang et al. have observed that in a $\mathrm{ZVI} / \mathrm{H}_{2} \mathrm{O}_{2} / \mathrm{MW}$ system, the reaction rate constant decreased from 0.05 to $0.01 \mathrm{~min}^{-1}$ when the initial $\mathrm{pH}$ increased from 2 to 8 [105]. They related this result to the formation of iron-based colloids in alkaline conditions, which undergo coagulation phenomena and slow down pollutant removal [105]. Lee et al. have proposed that MW radiation may be absorbed unequally by ZVI particles, with formation of local hot spots having much higher surface temperature $\left(435^{\circ} \mathrm{C}\right)$ than the surrounding zones [106]. The temperature increase could induce higher ZVI reactivity and enhance the release of $\mathrm{Fe}^{2+}$ ions into the solution. In addition, under MW irradiation the mass transport accelerates at all $\mathrm{pH}$ values, because of an increase in the average kinetic energy and thermal motion of the molecules [107]. Hong et al. have suggested that not only strongly acidic conditions, but also strongly alkaline conditions $(\mathrm{pH} \approx 12)$ could sharply enhance Rhodamine B decomposition in a $\mathrm{H}_{2} \mathrm{O}_{2} / \mathrm{MW}$ system. They found that $\mathrm{H}_{2} \mathrm{O}_{2}$ was decomposed into $\mathrm{O}_{2}$ in the presence of MW irradiation at $\mathrm{pH} 12$, and $\mathrm{O}_{2}$ was then involved in substrate oxidation [108]. Moreover, some organic compounds such as phenols are in the anionic state at alkaline $\mathrm{pH}$, where they absorb microwave radiation to a larger extent than at other $\mathrm{pH}$ values. Interestingly, pollutant degradation with $\mathrm{H}_{2} \mathrm{O}_{2} / \mathrm{MW}$ behaved differently from ${ }^{\bullet} \mathrm{OH}$ oxidation [108]. Remya and Lin have reported that carbofuran degradation by $\mathrm{ZVI} / \mathrm{H}_{2} \mathrm{O}_{2} / \mathrm{MW}$ at $80^{\circ} \mathrm{C}$ increased by increasing $\mathrm{pH}$ from 2 to 10 [109]. From the results of their study, 99-100\% degradation of carbofuran was achieved after $60 \mathrm{~min}$ at $\mathrm{pH} 6$. By increasing the $\mathrm{pH}$ to 8 , the time needed for complete carbofuran decomposition decreased to $10 \mathrm{~min}$. The cited authors suggested that the higher efficiency of ZVI at alkaline $\mathrm{pH}$ was probably due to radical oxidation processes, i.e., the transformation of $\mathrm{OH}^{-}$anions into hydroxyl radicals due to the loss of electrons at higher temperature in the presence of MW [109]. Liu and coworkers have reported that the removal rates of 4-nitrophenol using a ZVI/MW system at ambient temperature were almost equal at $\mathrm{pH}$ 3 and 7 [110]. The same result has been observed by Jou for the removal of pentachlorophenol by $\mathrm{ZVI} / \mathrm{MW}$ in water [111]. In the presence of $\mathrm{MW}, \mathrm{Fe}^{0}$ and pentachlorophenol $\left(\mathrm{C}_{6} \mathrm{Cl}_{5} \mathrm{OH}\right)$ formed $\mathrm{Cl}^{-}$and $\mathrm{Cl}_{2}$, which reacted with water vapor to produce $\mathrm{HCl}$. The acid dropped the solution $\mathrm{pH}$ and intensified ZVI corrosion [111-114]. Although further studies are required to better understand the behavior of $\mathrm{ZVI} / \mathrm{H}_{2} \mathrm{O}_{2} / \mathrm{MW}$ systems, generally it can be concluded that the addition of MW to $\mathrm{ZVI} / \mathrm{H}_{2} \mathrm{O}_{2}$ enhances the degradation rate of contaminants at $\mathrm{pH}$ ranges from acidic to alkaline. However, the reaction pathway could substantially depart from a typical Fenton process. Moreover, the power consumption of microwave is always a concern in practical applications [93]. A typical microwave-ZVI Fenton system is shown in Figure 5.

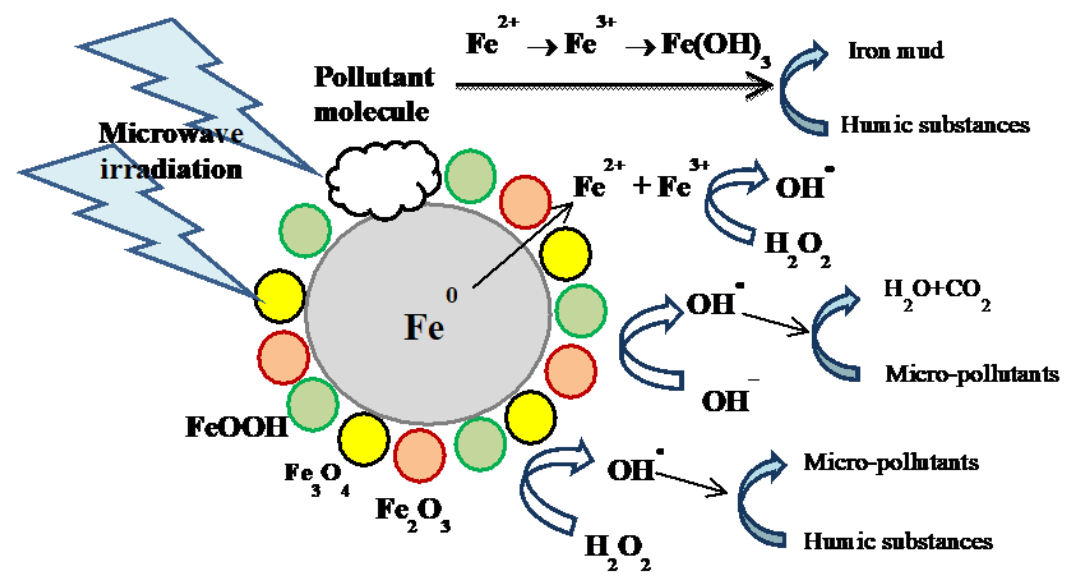

Figure 5. Typical microwave (MW)-ZVI-Fenton system. Reproduced with permission from Reference [17]. 


\section{Conclusions}

In summary, pH significantly affects the ZVI performance for contaminants removal in ZVI-based heterogeneous Fenton processes. High degradation efficiencies are usually obtained in the $\mathrm{pH}$ range $3-4$, which is mainly attributed to acceleration of iron corrosion, dissolution of the passive oxide layers on the ZVI surface, and efficient generation of hydroxyl radicals. In contrast, neutral and alkaline $\mathrm{pH}$ values decrease the ZVI-Fenton efficiency due to Fe(III) precipitation (or lack of solubility) and less effective ${ }^{\bullet} \mathrm{OH}$ production. A decrease of the solution $\mathrm{pH}$ below 3 could be detrimental to degradation, because it causes fast dissolution of ZVI particles, leads to an excessive accumulation of hydrogen bubbles at the ZVI interface, or both. These phenomena may decrease the available reactive surface area for contaminants removal. In addition, the solution $\mathrm{pH}$ alters the surface charge distribution of iron hydroxides/oxides, causes ionization of weak acid or bases (depending on their $\mathrm{pK}_{\mathrm{a}}$ values), and affects solubility, speciation, as well as complex formation tendency of metal or metalloid contaminants. For example, increasing the solution $\mathrm{pH}$ to moderately basic conditions can favor the removal of some metal cations (e.g., $\mathrm{Cu}^{2+}, \mathrm{Cd}^{2+}, \mathrm{Zn}^{2+}, \mathrm{Co}^{2+}$ ) by enhancing their adsorption to iron oxides that coat the ZVI surface, or their precipitation as metal hydroxides. At $\mathrm{pH}$ values below the point of zero charge $\left(\mathrm{pH}_{\mathrm{PZC}}\right)$, the surface of $\mathrm{ZVI}$ is positive and it may attract negatively charged pollutants (e.g., $\mathrm{Cr}(\mathrm{VI})$ and $\mathrm{As}(\mathrm{V}))$.

Fenton-like processes, by addition of external energy to the heterogeneous Fenton reaction, can increase the ZVI performance to remove contaminants in a wide range of $\mathrm{pH}$ values. Moreover, the regeneration of ferrous ions can be accelerated. The combination of heterogeneous Fenton with a weak magnetic field, UV irradiation, ultrasound or microwave irradiation looks promising, although such techniques might be more difficult to apply in large-scale operations than in the laboratory. The generation of oxidizing radicals in Fenton-like processes may be almost independent of the solution $\mathrm{pH}$ in some cases, but ZVI corrosion is still influenced by $\mathrm{pH}$. Many studies have shown the high performance of ZVI at acidic and neutral $\mathrm{pH}$ values in the framework of Fenton-like processes, but additional work is required to investigate the effect of strong alkaline conditions (e.g., $\mathrm{pH}$ values of 11-12) on the efficiency of ZVI-Fenton-like systems. Interestingly, in the context of industrial applications, other wastewater treatment methods such as filtration and biological treatment can also be coupled with Fenton-like techniques to achieve complete removal of organic pollutants.

Author Contributions: F.R. carried out the bibliographic research and wrote the manuscript draft, D.V. conceived the work and corrected the manuscript.

Funding: D.V. acknowledges financial support by University of Torino and Compagnia di San Paolo (project CSTO168282-ABATEPHARM). F.R. acknowledges the Tarbiat Modares University for providing extensive access to scientific databases and gratefully appreciates Dr. Hiwa Hossaini from Kermanshah University of Medical Sciences (KUMS) for his valuable and constructive suggestions to develop the idea of the present manuscript.

Conflicts of Interest: The authors declare no conflict of interest. The funding sponsors had no role in the design of the study; in the collection, analyses, or interpretation of data; in the writing of the manuscript, and in the decision to publish.

\section{References}

1. Santos-Juanesa, L.; García Einschlagb, F.S.; Amata, A.M.; Arques, A. Combining ZVI reduction with photo-Fenton process for the removal of persistent pollutants. Chem. Eng. J. 2017, 310, 484-490. [CrossRef]

2. Segura, Y.; Martínez, F.; Melero, J.A. Effective pharmaceutical wastewater degradation by Fenton oxidation with zero-valent iron. Appl. Catal. B Environ. 2013, 136-137, 64-69. [CrossRef]

3. Segura, Y.; Martínez, F.; Melero, J.A.; Fierro, J.L.G. Zero valent iron (zvi) mediated fenton degradation of industrial wastewater: Treatment performance and characterization of final composites. Chem. Eng. J. 2015, 269, 298-305. [CrossRef]

4. Martins, R.C.; Henriques, L.R.; Quinta-Ferreira, R.M. Catalytic activity of low cost materials for pollutants abatement by Fenton's process. Chem. Eng. Sci. 2013, 100, 225-233. [CrossRef] 
5. Weng, C.-H.; Lin, Y.-T.; Chang, C.-K.; Liu, N. Decolourization of direct blue 15 by fenton/ultrasonic process using a zero-valent iron aggregate catalyst. Ultrason. Sonochem. 2013, 20, 970-977. [CrossRef] [PubMed]

6. Bogacki, J.; Marcinowski, P.; Zapałowska, E.; Maksymiec, J.; Naumczyk, J. Cosmetic wastewater treatment by the ZVI/ $\mathrm{H}_{2} \mathrm{O}_{2}$ process. Environ. Technol. 2017, 38, 2589-2600. [CrossRef] [PubMed]

7. Grčić, I.; Papić, S.; Žižek, K.; Koprivanac, N. Zero-valent iron (ZVI) Fenton oxidation of reactive dye wastewater under UV-C and solar irradiation. Chem. Eng. J. 2012, 195-196, 77-90. [CrossRef]

8. Aljuboury, A.; Palaniandy, P.; Aziz, H.B.A.; Feroz, S. A Review on the Fenton Process for Wastewater Treatment. Available online: https://www.researchgate.net/publication/282148450_A_Review_on_the_ Fenton_Process_for_Wastewater_Treatment (accessed on 1 November 2018).

9. Matavos-Aramyan, S.; Moussavi, M. Advances in Fenton and Fenton Based Oxidation Processes for Industrial Effluent Contaminants Control-A Review. Int. J. Environ. Sci. Nat. Resour. 2017, 2, 555594. [CrossRef]

10. He, J.; Yang, X.; Men, B.; Wang, D. Interfacial mechanisms of heterogeneous Fenton reactions catalyzed by iron-based materials: A review. J. Environ. Sci. 2016, 39, 97-109. [CrossRef] [PubMed]

11. Pereira, M.C.; Oliveira, L.C.A.; Murad, E. Iron oxide catalysts: Fenton and Fenton-like reactions: A review. Clay Miner. 2012, 47, 285-302. [CrossRef]

12. Rahim Pouran, S.; Abdul Raman, A.A.; Wan Daud, W.M.A. Review on the application of modified iron oxides as heterogeneous catalysts in Fenton reactions. J. Clean. Prod. 2014, 64, 24-35. [CrossRef]

13. Wu, Y.; Yao, H.; Khan, S.; Hu, S.; Wang, L. Characteristics and Mechanisms of Kaolinite-Supported Zero-Valent Iron $/ \mathrm{H}_{2} \mathrm{O}_{2}$ System for Nitrobenzene Degradation. CLEAN Soil Air. Water 2017, 45, 1600826. [CrossRef]

14. Dos Santos, F.S.; Lago, F.R.; Yokoyama, L.; Fonseca, F.V. Synthesis and characterization of zero-valent iron nanoparticles supported on SBA-15. J. Mater. Res. Technol. 2017, 6, 178-183. [CrossRef]

15. Fontecha-Cámara, M.A.; Álvarez-Merino, M.A.; Carrasco-Marín, F.; López-Ramón, M.V.; Moreno-Castilla, C. Heterogeneous and homogeneous fenton processes using activated carbon for the removal of the herbicide amitrole from water. Appl. Catal. B Environ. 2011, 101, 425-430. [CrossRef]

16. Lin, C.-C.; Chen, Y.-H. Feasibility of using nanoscale zero-valent iron and persulfate to degrade sulfamethazine in aqueous solutions. Sep. Purif. Technol. 2018, 194, 388-395. [CrossRef]

17. Chen, W.; Zhang, A.; Gu, Z.; Li, Q. Enhanced degradation of refractory organics in concentrated landfill leachate by $\mathrm{Fe}^{0} / \mathrm{H}_{2} \mathrm{O}_{2}$ coupled with microwave irradiation. Chem. Eng. J. 2018, 354, 680-691. [CrossRef]

18. Crane, R.A.; Scott, T.B. Nanoscale zero-valent iron: Future prospects for an emerging water treatment technology. J. Hazard. Mater. 2012, 211-212, 112-125. [CrossRef] [PubMed]

19. Lei, C.; Sun, Y.; Tsang, D.C.W.; Lin, D. Environmental transformations and ecological effects of iron-based nanoparticles. Environ. Pollut. 2018, 232, 10-30. [CrossRef] [PubMed]

20. Raman, C.D.; Kanmani, S. Textile dye degradation using nano zero valent iron: A review. J. Environ. Manag. 2016, 177, 341-355. [CrossRef] [PubMed]

21. Colombo, A.; Dragonetti, C.; Magni, M.; Roberto, D. Degradation of toxic halogenated organic compounds by iron-containing mono-, bi- and tri-metallic particles in water. Inorg. Chim. Acta. 2015, 431, 48-60. [CrossRef]

22. Naldoni, A.; Schiboula, A.; Bianchi, C.L.; Bremner, D.H. Mineralisation of surfactants using ultrasound and the advanced fenton process. Water Air Soil Pollut. 2011, 215, 487-495. [CrossRef]

23. Alowitz, M.J.; Scherer, M.M. Kinetics of Nitrate, Nitrite, and Cr(VI) Reduction by Iron Metal. Environ. Sci. Technol. 2002, 36, 299-306. [CrossRef] [PubMed]

24. Zhao, L.; Ji, Y.; Kong, D.; Lu, J.; Zhou, Q.; Yin, X. Simultaneous removal of bisphenol A and phosphate in zero-valent iron activated persulfate oxidation process. Chem. Eng. J. 2016, 303, 458-466. [CrossRef]

25. Yamaguchi, R.; Kurosu, S.; Suzuki, M.; Kawase, Y. Hydroxyl radical generation by zero-valent iron/Cu $(\mathrm{ZVI} / \mathrm{Cu})$ bimetallic catalyst in wastewater treatment: Heterogeneous Fenton/Fenton-like reactions by Fenton reagents formed in-situ under oxic conditions. Chem. Eng. J. 2018, 334, 1537-1549. [CrossRef]

26. Guo, X.; Yang, Z.; Dong, H.; Guan, X.; Ren, Q.; Lv, X.; Jin, X. Simple combination of oxidants with zero-valent-iron (ZVI) achieved very rapid and highly efficient removal of heavy metals from water. Water Res. 2016, 88, 671-680. [CrossRef] [PubMed]

27. Volpe, A.; Pagano, M.; Mascolo, G.; Lopez, A.; Ciannarella, R.; Locaputo, V. Simultaneous Cr(VI) reduction and non-ionic surfactant oxidation by peroxymonosulphate and iron powder. Chemosphere 2013, 91, 1250-1256. [CrossRef] [PubMed]

28. Klas, S.; Kirk, D.W. Advantages of low $\mathrm{pH}$ and limited oxygenation in arsenite removal from water by zero-valent iron. J. Hazard. Mater. 2013, 252-253, 77-82. [CrossRef] [PubMed] 
29. Donadelli, J.A.; Carlos, L.; Arques, A.; García Einschlag, F.S. Kinetic and mechanistic analysis of azo dyes decolorization by ZVI-assisted Fenton systems: $\mathrm{pH}$-dependent shift in the contributions of reductive and oxidative transformation pathways. Appl. Catal. B Environ. 2018, 231, 51-61. [CrossRef]

30. Lai, B.; Zhang, Y.H.; Li, R.; Zhou, Y.X.; Wang, J. Influence of operating temperature on the reduction of high concentration p-nitrophenol (PNP) by zero valent iron (ZVI). Chem. Eng. J. 2014, 249, 143-152. [CrossRef]

31. Nidheesh, P.V. Heterogeneous Fenton catalysts for the abatement of organic pollutants from aqueous solution: A review. RSC Adv. 2015, 5, 40552-40577. [CrossRef]

32. Enami, S.; Sakamoto, Y.; Colussi, A.J. Fenton chemistry at aqueous interfaces. Proc. Natl. Acad. Sci. 2014, 111, 623-628. [CrossRef] [PubMed]

33. Bouse, S.A. The Removal of Selenium From Water Using Zero Valent Iron Systems ZVI Medium. Available online: http://www.zerovalent.com/images/White-Paper-The-Removal-of-Selenium-fromWater-using-Zero-Valent-Iron-Systems-ZVI-Medium.pdf (accessed on 1 November 2018).

34. Fu, F.; Lu, J.; Cheng, Z.; Tang, B. Removal of selenite by zero-valent iron combined with ultrasound: Se(IV) concentration changes, Se(VI) generation, and reaction mechanism. Ultrason. Sonochem. 2016, 29, 328-336. [CrossRef] [PubMed]

35. Zhao, X.; Liu, W.; Cai, Z.; Han, B.; Qian, T.; Zhao, D. An overview of preparation and applications of stabilized zero-valent iron nanoparticles for soil and groundwater remediation. Water Res. 2016, 100, $245-266$. [CrossRef] [PubMed]

36. Huang, Y.H.; Tang, C.; Zeng, H. Removing molybdate from water using a hybridized zero-valent iron/magnetite/Fe(II) treatment system. Chem. Eng. J. 2012, 200-202, 257-263. [CrossRef]

37. Sun, Y.P.; Li, X.; Cao, J.; Zhang, W.; Wang, H.P. Characterization of zero-valent iron nanoparticles. Adv. Colloid Interface Sci. 2006, 120, 47-56. [CrossRef] [PubMed]

38. Ensing, B.; Buda, F.; Baerends, E.J. Fenton-like Chemistry in Water: Oxidation Catalysis by $\mathrm{Fe}(\mathrm{III})$ and $\mathrm{H}_{2} \mathrm{O}_{2}$. J. Phys. Chem. A 2003, 107, 5722-5731. [CrossRef]

39. Diya'uddeen, B.H.; Abdul Aziz, A.R.; Wan Daud, W.M.A. On the Limitation of Fenton Oxidation Operational Parameters: A Review. Int. J. Chem. React. Eng. 2012, 10. [CrossRef]

40. Jing, C.; Li, Y.L.; Landsberger, S. Review of soluble uranium removal by nanoscale zero valent iron. J. Environ. Radioact. 2016, 164, 65-72. [CrossRef] [PubMed]

41. Zhang, Y.; Jing, Y.; Zhang, J.; Sun, L.; Quan, X. Performance of a ZVI-UASB reactor for azo dye wastewater treatment. J. Chem. Technol. Biotechnol. 2011, 86, 199-204. [CrossRef]

42. Ling, L.; Zhang, W. Sequestration of Arsenate in Zero-Valent Iron Nanoparticles: Visualization of Intraparticle Reactions at Angstrom Resolution. Environ. Sci. Technol. Lett. 2014, 1, 305-309. [CrossRef]

43. Wang, Y.; Shao, Q.; Huang, S.; Zhang, B.; Xu, C. High performance and simultaneous sequestration of Cr(VI) and $\mathrm{Sb}(\mathrm{III})$ by sulfidated zerovalent iron. J. Clean. Prod. 2018, 191, 436-444. [CrossRef]

44. Xu, C.; Zhang, B.; Zhu, L.; Lin, S.; Sun, X.; Jiang, Z.; Tratnyek, P.G. Sequestration of Antimonite by Zerovalent Iron: Using Weak Magnetic Field Effects to Enhance Performance and Characterize Reaction Mechanisms. Environ. Sci. Technol. 2016, 50, 1483-1491. [CrossRef] [PubMed]

45. Chen, X.; Ji, D.; Wang, X.; Zang, L. Review on Nano zerovalent Iron (nZVI): From Modification to Environmental Applications. IOP Conf. Ser. Earth Environ. Sci. 2017, 51, 012004. [CrossRef]

46. Wang, N.; Zheng, T.; Zhang, G.; Wang, P. A review on Fenton-like processes for organic wastewater treatment. J. Environ. Chem. Eng. 2016, 4, 762-787. [CrossRef]

47. Harada, T.; Yatagai, T.; Kawase, Y. Hydroxyl radical generation linked with iron dissolution and dissolved oxygen consumption in zero-valent iron wastewater treatment process. Chem. Eng. J. 2016, 303, 611-620. [CrossRef]

48. Rosales, E.; Sanromán, M.Á.; Dias-Ferreira, C. Green zero-valent iron nanoparticles synthesized using herbal extracts for degradation of dyes from wastewater. Desalin. Water Treat. 2017, 92, 159-167. [CrossRef]

49. Soleymanzadeh, M.; Arshadi, M.; Salvacion, J.W.L.; SalimiVahid, F. A new and effective nanobiocomposite for sequestration of $\mathrm{Cd}(\mathrm{II})$ ions: Nanoscale zerovalent iron supported on sineguelas seed waste. Chem. Eng. Res. Des. 2015, 93, 696-709. [CrossRef]

50. Miehr, R.; Tratnyek, P.G.; Bandstra, J.Z.; Scherer, M.M.; Lowitz, M.J.; Bylaska, A.E.J. Diversity of contaminant reduction reactions by zerovalent iron: Role of the reductate. Environ. Sci. Technol. 2004, 38, 139-147. [CrossRef] [PubMed] 
51. Hu, J.; Chen, G.; Lo, I.M.C. Selective removal of heavy metals from industrial wastewater using maghemite nanoparticles: Performance and mechanisms. J. Environ. Eng. 2006, 132, 709-715. [CrossRef]

52. Cao, J.; Xiong, Z.; Lai, B. Effect of initial $\mathrm{pH}$ on the tetracycline (TC) removal by zero-valent iron: Adsorption, oxidation and reduction. Chem. Eng. J. 2018, 343, 492-499. [CrossRef]

53. Yoshino, H.; Kurosu, S.; Yamaguchi, R.; Kawase, Y. A phenomenological reaction kinetic model for Cu removal from aqueous solutions by zero-valent iron (ZVI). Chemosphere 2018, 200, 542-553. [CrossRef] [PubMed]

54. Qin, H.; Li, J.; Bao, Q.; Li, L.; Guan, X. Role of dissolved oxygen in metal(loid) removal by zerovalent iron at different $\mathrm{pH}$ : Its dependence on the removal mechanisms. RSC Adv. 2016, 6, 50144-50152. [CrossRef]

55. Rangsivek, R.; Jekel, M.R. Removal of dissolved metals by zero-valent iron (ZVI): Kinetics, equilibria, processes and implications for stormwater runoff treatment. Water Res. 2005, 39, 4153-4163. [CrossRef] [PubMed]

56. Jiang, X.; Qiao, J.; Lo, I.M.C.; Wang, L.; Guan, X.; Lu, Z.; Zhou, G.; Xu, C. Enhanced paramagnetic Cu ${ }^{2+}$ ions removal by coupling a weak magnetic field with zero valent iron. J. Hazard. Mater. 2015, 283, 880-887. [CrossRef] [PubMed]

57. Bae, S.; Hanna, K. Reactivity of Nanoscale Zero-Valent Iron in Unbuffered Systems: Effect of pH and Fe(II) Dissolution. Environ. Sci. Technol. 2015, 49, 10536-10543. [CrossRef] [PubMed]

58. Prasad Rao, J.; Gruenberg, P.; Geckeler, K.E. Magnetic zero-valent metal polymer nanoparticles: Current trends, scope, and perspectives. Prog. Polym. Sci. 2015, 40, 138-147. [CrossRef]

59. Yirsaw, B.D.; Megharaj, M.; Chen, Z.; Naidu, R. Environmental application and ecological significance of nano-zero valent iron. J. Environ. Sci. 2016, 44, 88-98. [CrossRef] [PubMed]

60. Patil, S.S.; Shedbalkar, U.U.; Truskewycz, A.; Chopade, B.A.; Ball, A.S. Nanoparticles for environmental clean-up: A review of potential risks and emerging solutions. Environ. Technol. Innov. 2016, 5, 10-21. [CrossRef]

61. Chekli, L.; Bayatsarmadi, B.; Sekine, R.; Sarkar, B.; Shen, A.M.; Scheckel, K.G.; Skinner, W.; Naidu, R.; Shon, H.K.; Lombi, E.; et al. Analytical characterisation of nanoscale zero-valent iron: A methodological review. Anal. Chim. Acta. 2016, 903, 13-35. [CrossRef] [PubMed]

62. Mwakabona, H.T.; Ndé-Tchoupé, A.I.; Njau, K.N.; Noubactep, C.; Wydra, K.D. Metallic iron for safe drinking water provision: Considering a lost knowledge. Water Res. 2017, 117, 127-142. [CrossRef] [PubMed]

63. Tosco, T.; Petrangeli Papini, M.; Cruz Viggi, C.; Sethi, R. Nanoscale zerovalent iron particles for groundwater remediation: A review. J. Clean. Prod. 2014, 77, 10-21. [CrossRef]

64. Chiu, P.C. Applications of zero-valent iron (ZVI) and nanoscale ZVI to municipal and decentralized drinking water systems-A review. ACS Symp. Ser. 2013, 1123, 237-249. [CrossRef]

65. Xu, Y.; Wang, C.; Hou, J.; Wang, P.; You, G.; Miao, L.; Lv, B.; Yang, Y.; Zhang, F. Application of zero valent iron coupling with biological process for wastewater treatment: A review. Rev. Environ. Sci. Bio/Technol. 2017, 16, 667-693. [CrossRef]

66. Boontian, N. Effect of Zero Valent Iron (ZVI) in Wastewater Treatment: A Review. Appl. Mech. Mater. 2015, 775, 180-184. [CrossRef]

67. Jafari, S.J.; Moussavi, G.; Hossaini, H. Degradation and mineralization of diazinon pesticide in UVC and UVC/TiO2 process. Desalin. Water Treat. 2016, 57, 3782-3790. [CrossRef]

68. Sun, Y.; Li, J.; Huang, T.; Guan, X. The influences of iron characteristics, operating conditions and solution chemistry on contaminants removal by zero-valent iron: A review. Water Res. 2016, 100, 277-295. [CrossRef] [PubMed]

69. Pourfadakari, S.; Yousefi, N.; Mahvi, A.H. Removal of Reactive Red 198 from aqueous solution by combined method multi-walled carbon nanotubes and zero-valent iron: Equilibrium, kinetics, and thermodynamic. Chinese J. Chem. Eng. 2016, 24, 1448-1455. [CrossRef]

70. Yang, Z.; Ma, X.; Shan, C.; Fang, Z.; Pan, B. Enhanced Nitrobenzene reduction by zero valent iron pretreated with $\mathrm{H}_{2} \mathrm{O}_{2} / \mathrm{HCl}$. Chemosphere 2018, 197, 494-501. [CrossRef] [PubMed]

71. Ershadi, L.; Ebadi, T.; Ershadi, V. Chemical oxidation of crude oil in oil contaminated soil by Fenton process using nano zero valent Iron. Int. Conf. Environ. Sci. Technol. 2011, 6, 89-91.

72. Hartmann, M.; Kullmann, S.; Keller, H. Wastewater treatment with heterogeneous Fenton-type catalysts based on porous materials. J. Mater. Chem. 2010, 20, 9002. [CrossRef]

73. Pignatello, J.J.; Oliveros, E.; MacKay, A. Advanced oxidation processes for organic contaminant destruction based on the Fenton reaction and related chemistry. Crit. Rev. Environ. Sci. Technol. 2006, 36, 1-84. [CrossRef] 
74. Lai, B.; Chen, Z.; Zhou, Y.; Yang, P.; Wang, J.; Chen, Z. Removal of high concentration p-nitrophenol in aqueous solution by zero valent iron with ultrasonic irradiation (US-ZVI). J. Hazard. Mater. 2013, 250-251, 220-228. [CrossRef] [PubMed]

75. Malakootian, M.; Daneshkhah, M.; Hossaini, H. Removal of phosphates from aqueous solution by sepiolite-nano zero valent iron composite optimization with response surface methodology. Int. J. Environ. Sci. Technol. 2018, 15, 2129-2140. [CrossRef]

76. Ling, R.; Chen, J.P.; Shao, J.; Reinhard, M. Degradation of organic compounds during the corrosion of ZVI by hydrogen peroxide at neutral $\mathrm{pH}$ : Kinetics, mechanisms and effect of corrosion promoting and inhibiting ions. Water Res. 2018, 134, 44-53. [CrossRef] [PubMed]

77. Zhang, W.; Gao, H.; He, J.; Yang, P.; Wang, D.; Ma, T.; Xia, H.; Xu, X. Removal of norfloxacin using coupled synthesized nanoscale zero-valent iron (nZVI) with $\mathrm{H}_{2} \mathrm{O}_{2}$ system: Optimization of operating conditions and degradation pathway. Sep. Purif. Technol. 2017, 172, 158-167. [CrossRef]

78. Khan, A.; Prabhu, S.M.; Park, J.; Lee, W.; Chon, C.-M.; Ahn, J.S.; Lee, G. Azo dye decolorization by ZVI under circum-neutral $\mathrm{pH}$ conditions and the characterization of ZVI corrosion products. J. Ind. Eng. Chem. 2017, 47, 86-93. [CrossRef]

79. Yuan, Y.; Lai, B.; Yang, P.; Zhou, Y. Treatment of ammunition wastewater by the combined $\mathrm{Fe}^{0} /$ air and Fenton process (1st Fe ${ }^{0}$ /air-Fenton-2nd $\mathrm{Fe}^{0}$ /air). J. Taiwan Inst. Chem. Eng. 2016, 65, 286-294. [CrossRef]

80. Cheng, R.; Cheng, C.; Liu, G.; Zheng, X.; Li, G.; Li, J. Removing pentachlorophenol from water using a nanoscale zero-valent iron $/ \mathrm{H}_{2} \mathrm{O}_{2}$ system. Chemosphere 2015, 141, 138-143. [CrossRef] [PubMed]

81. Shen, J.; Ou, C.; Zhou, Z.; Chen, J.; Fang, K.; Sun, X.; Li, J.; Zhou, L.; Wang, L. Pretreatment of 2,4-dinitroanisole (DNAN) producing wastewater using a combined zero-valent iron (ZVI) reduction and Fenton oxidation process. J. Hazard. Mater. 2013, 260, 993-1000. [CrossRef] [PubMed]

82. Katsoyiannis, I.A.; Ruettimann, T.; Hug, S.J. pH dependence of fenton reagent generation and As(III) oxidation and removal by corrosion of zero valent iron in aerated water. Environ. Sci. Technol. 2008, 42, 7424-7430. [CrossRef] [PubMed]

83. Song, H.; Carraway, E.R. Reduction of Chlorinated Methanes by Nano-Sized Zero-Valent Iron. Kinetics, Pathways, and Effect of Reaction Conditions. Environ. Eng. Sci. 2006, 23, 272-284. [CrossRef]

84. Shahwan, T.; Abu Sirriah, S.; Nairat, M.; Boyaci, E.; Eroĝlu, A.E.; Scott, T.B.; Hallam, K.R. Green synthesis of iron nanoparticles and their application as a Fenton-like catalyst for the degradation of aqueous cationic and anionic dyes. Chem. Eng. J. 2011, 172, 258-266. [CrossRef]

85. Moon, B.H.; Park, Y.B.; Park, K.H. Fenton oxidation of Orange II by pre-reduction using nanoscale zero-valent iron. Desalination 2011, 268, 249-252. [CrossRef]

86. Zha, S.; Cheng, Y.; Gao, Y.; Chen, Z.; Megharaj, M.; Naidu, R. Nanoscale zero-valent iron as a catalyst for heterogeneous Fenton oxidation of amoxicillin. Chem. Eng. J. 2014, 255, 141-148. [CrossRef]

87. Xu, L.; Wang, J. A heterogeneous Fenton-like system with nanoparticulate zero-valent iron for removal of 4-chloro-3-methyl phenol. J. Hazard. Mater. 2011, 186, 256-264. [CrossRef] [PubMed]

88. Zhou, T.; Li, Y.; Ji, J.; Wong, F.S.; Lu, X. Oxidation of 4-chlorophenol in a heterogeneous zero valent iron $/ \mathrm{H}_{2} \mathrm{O}_{2}$ Fenton-like system: Kinetic, pathway and effect factors. Sep. Purif. Technol. 2008, 62, 551-558. [CrossRef]

89. Vilardi, G.; Di Palma, L.; Verdone, N. On the critical use of zero valent iron nanoparticles and Fenton processes for the treatment of tannery wastewater. J. Water Process. Eng. 2018, 22, 109-122. [CrossRef]

90. Bergendahl, J.A.; Thies, T.P. Fenton's oxidation of MTBE with zero-valent iron. Water Res. 2004, 38, 327-334. [CrossRef] [PubMed]

91. Yoon, I.H.; Yoo, G.; Hong, H.J.; Kim, J.; Kim, M.G.; Choi, W.K.; Yang, J.W. Kinetic study for phenol degradation by ZVI-assisted Fenton reaction and related iron corrosion investigated by X-ray absorption spectroscopy. Chemosphere 2016, 145, 409-415. [CrossRef] [PubMed]

92. Barbusiński, K. Controversy Over Fenton Mechanism. Ecol. Chem. Eng. 2009, 16, 347-358.

93. Guan, X.; Sun, Y.; Qin, H.; Li, J.; Lo, I.M.C.; He, D.; Dong, H. The limitations of applying zero-valent iron technology in contaminants sequestration and the corresponding countermeasures: The development in zero-valent iron technology in the last two decades (1994-2014). Water Res. 2015, 75, 224-248. [CrossRef] [PubMed]

94. Xiong, Z.; Lai, B.; Yang, P.; Zhou, Y.; Wang, J.; Fang, S. Comparative study on the reactivity of Fe/Cu bimetallic particles and zero valent iron (ZVI) under different conditions of $\mathrm{N}_{2}$, air or without aeration. J. Hazard. Mater. 2015, 297, 261-268. [CrossRef] [PubMed] 
95. Joo, S.H.; Feitz, A.J.; Waite, T.D. Oxidative Degradation of the Carbothioate Herbicide, Molinate, Using Nanoscale Zero-Valent Iron. Environ. Sci. Technol. 2004, 38, 2242-2247. [CrossRef] [PubMed]

96. Zhou, T.; Feng, K.; Xiang, W.; Lv, Y.; Wu, X.; Mao, J.; He, C. Rapid decomposition of diclofenac in a magnetic field enhanced zero-valent iron/EDTA Fenton-like system. Chemosphere 2018, 193, 968-977. [CrossRef] [PubMed]

97. Xiang, W.; Zhang, B.; Zhou, T.; Wu, X.; Mao, J. An insight in magnetic field enhanced zero-valent iron $/ \mathrm{H}_{2} \mathrm{O}_{2}$ Fenton-like systems: Critical role and evolution of the pristine iron oxides layer. Sci. Rep. 2016, 6, 24094. [CrossRef] [PubMed]

98. Pan, Y.; Zhou, M.; Cai, J.; Li, X.; Wang, W.; Li, B.; Sheng, X.; Tang, Z. Significant enhancement in treatment of salty wastewater by pre-magnetization $\mathrm{Fe}^{0} / \mathrm{H}_{2} \mathrm{O}_{2}$ process. Chem. Eng. J. 2018, 339, 411-423. [CrossRef]

99. Liang, L.; Sun, W.; Guan, X.; Huang, Y.; Choi, W.; Bao, H.; Li, L.; Jiang, Z. Weak magnetic field significantly enhances selenite removal kinetics by zero valent iron. Water Res. 2014, 49, 371-380. [CrossRef] [PubMed]

100. Xiong, X.; Sun, B.; Zhang, J.; Gao, N.; Shen, J.; Li, J.; Guan, X. Activating persulfate by Fe ${ }^{0}$ coupling with weak magnetic field: Performance and mechanism. Water Res. 2014, 62, 53-62. [CrossRef] [PubMed]

101. Feng, P.; Guan, X.; Sun, Y.; Choi, W.; Qin, H.; Wang, J.; Qiao, J.; Li, L. Weak magnetic field accelerates chromate removal by zero-valent iron. J. Environ. Sci. 2015, 31, 175-183. [CrossRef] [PubMed]

102. Man, X.; Ning, X.; Zou, H.; Liang, J.; Sun, J.; Lu, X.; Sun, J. Removal of polycyclic aromatic hydrocarbons (PAHs) from textile dyeing sludge by ultrasound combined zero-valent iron/EDTA/Air system. Chemosphere 2018, 191, 839-847. [CrossRef] [PubMed]

103. Zhou, H.; Shen, Y.; Lv, P.; Wang, J.; Li, P. Degradation pathway and kinetics of 1-alkyl-3-methylimidazolium bromides oxidation in an ultrasonic nanoscale zero-valent iron/hydrogen peroxide system. J. Hazard. Mater. 2015, 284, 241-252. [CrossRef] [PubMed]

104. Minella, M.; Sappa, E.; Hanna, K.; Barsotti, F.; Maurino, V.; Minero, C.; Vione, D. Considerable Fenton and photo-Fenton reactivity of passivated zero-valent iron. RSC Adv. 2016, 6, 86752-86761. [CrossRef]

105. Rahim Pouran, S.; Abdul Aziz, A.R.; Wan Daud, W.M.A. Review on the main advances in photo-Fenton oxidation system for recalcitrant wastewaters. J. Ind. Eng. Chem. 2015, 21, 53-69. [CrossRef]

106. Wang, C.; Liu, H.; Sun, Z. Heterogeneous photo-Fenton reaction catalyzed by nanosized iron oxides for water treatment. Int. J. Photoenergy. 2012, 2012. [CrossRef]

107. Rodríguez, M.; Malato, S.; Pulgarin, C.; Contreras, S.; Curcó, D.; Giménez, J.; Esplugas, S. Optimizing the solar photo-Fenton process in the treatment of contaminated water. Determination of intrinsic kinetic constants for scale-up. Sol. Energy. 2005, 79, 360-368. [CrossRef]

108. Zhang, A.; Gu, Z.; Chen, W.; Li, Q. Degradation of leachate from a semi-anaerobic aged refuse biofilter by the $\mathrm{ZVI} / \mathrm{H}_{2} \mathrm{O}_{2}$ process coupled with microwave irradiation: Optimization, organics transformation, and reaction mechanisms. Environ. Sci. Water Res. Technol. 2018, 4, 1695-1709. [CrossRef]

109. Lee, C.-L.; Jou, C.-J.G. Degradation of Chlorobenzene with Microwave-Aided Zerovalent Iron Particles. Environ. Eng. Sci. 2012, 29, 432-435. [CrossRef]

110. Fu, F.; Dionysiou, D.D.; Liu, H. The use of zero-valent iron for groundwater remediation and wastewater treatment: A review. J. Hazard. Mater. 2014, 267, 194-205. [CrossRef] [PubMed]

111. Hong, J.; Yuan, N.; Wang, Y.; Qi, S. Efficient degradation of Rhodamine B in microwave- $\mathrm{H}_{2} \mathrm{O}_{2}$ system at alkaline pH. Chem. Eng. J. 2012, 191, 364-368. [CrossRef]

112. Remya, N.; Lin, J.G. Microwave-assisted carbofuran degradation in the presence of GAC, ZVI and $\mathrm{H}_{2} \mathrm{O}_{2}$ : Influence of reaction temperature and $\mathrm{pH}$. Sep. Purif. Technol. 2011, 76, 244-252. [CrossRef]

113. Liu, B.; Li, S.; Zhao, Y.; Wu, W.; Zhang, X.; Gu, X.; Li, R.; Yang, S. Enhanced degradation of 4-nitrophenol by microwave assisted Fe/EDTA process. J. Hazard. Mater. 2010, 176, 213-219. [CrossRef] [PubMed]

114. Jou, C.J. Degradation of pentachlorophenol with zero-valence iron coupled with microwave energy. J. Hazard. Mater. 2008, 152, 699-702. [CrossRef] [PubMed]

(C) 2018 by the authors. Licensee MDPI, Basel, Switzerland. This article is an open access article distributed under the terms and conditions of the Creative Commons Attribution (CC BY) license (http:/ / creativecommons.org/licenses/by/4.0/). 